\title{
History, Geology, In Situ Stress Pattern, Gas Content and Permeability of Coal Seam Gas Basins in Australia: A Review
}

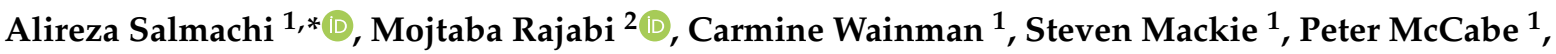 \\ Bronwyn Camac $^{3}$ and Christopher Clarkson ${ }^{4}$
}

1 Australian School of Petroleum and Energy Resources, University of Adelaide, Adelaide, SA 5005, Australia; carmine.wainman@adelaide.edu.au (C.W.); steven.mackie@adelaide.edu.au (S.M.); peter.mccabe@adelaide.edu.au (P.M.)

2 School of Earth and Environmental Sciences, University of Queensland, Brisbane, QLD 4072, Australia; m.rajabi@uq.edu.au

3 Santos Ltd., 60 Flinders Street, Adelaide, SA 5000, Australia; bronwyncamac2@bigpond.com

4 Department of Geoscience, University of Calgary, Calgary, AB T2N 1N4, Canada; clarksoc@ucalgary.ca

* Correspondence: alireza.salmachi@adelaide.edu.au

check for

updates

Citation: Salmachi, A.; Rajabi, M.; Wainman, C.; Mackie, S.; McCabe, P.; Camac, B.; Clarkson, C. History, Geology, In Situ Stress Pattern, Gas Content and Permeability of Coal Seam Gas Basins in Australia: A Review. Energies 2021, 14, 2651. https://doi.org/10.3390/en14092651

Academic Editor:

Nikolaos Koukouzas

Received: 23 March 2021

Accepted: 29 April 2021

Published: 5 May 2021

Publisher's Note: MDPI stays neutral with regard to jurisdictional claims in published maps and institutional affiliations.

Copyright: (C) 2021 by the authors Licensee MDPI, Basel, Switzerland. This article is an open access article distributed under the terms and conditions of the Creative Commons Attribution (CC BY) license (https:// creativecommons.org/licenses/by/ $4.0 /)$.

\begin{abstract}
Coal seam gas (CSG), also known as coalbed methane (CBM), is an important source of gas supply to the liquefied natural gas (LNG) exporting facilities in eastern Australia and to the Australian domestic market. In late 2018, Australia became the largest exporter of LNG in the world. $29 \%$ of the country's LNG nameplate capacity is in three east coast facilities that are supplied primarily by coal seam gas. Six geological basins including Bowen, Sydney, Gunnedah, Surat, Cooper and Gloucester host the majority of CSG resources in Australia. The Bowen and Surat basins contain an estimated 40Tcf of CSG whereas other basins contain relatively minor accumulations. In the Cooper Basin of South Australia, thick and laterally extensive Permian deep coal seams $(>2 \mathrm{~km}$ ) are currently underdeveloped resources. Since 2013, gas production exclusively from deep coal seams has been tested as a single add-on fracture stimulation in vertical well completions across the Cooper Basin. The rates and reserves achieved since 2013 demonstrate a robust statistical distribution ( $>130$ hydraulic fracture stages), the mean of which, is economically viable. The geological characteristics including coal rank, thickness and hydrogeology as well as the present-day stress pattern create favourable conditions for CSG production. Detailed analyses of high-resolution borehole image log data reveal that there are major perturbations in maximum horizontal stress $\left(\mathrm{S}_{\mathrm{Hmax}}\right)$ orientation, both spatially and with depth in Australian CSG basins, which is critical in hydraulic fracture stimulation and geomechanical modelling. Within a basin, significant variability in gas content and permeability may be observed with depth. The major reasons for such variabilities are coal rank, sealing capacity of overlying formations, measurement methods, thermal effects of magmatic intrusions, geological structures and stress regime. Field studies in Australia show permeability may enhance throughout depletion in CSG fields and the functional form of permeability versus reservoir pressure is exponential, consistent with observations in North American CSG fields.
\end{abstract}

Keywords: coal seam gas; coalbed methane; gas content; permeability; in situ stress; deep coal seams; geology

\section{Introduction}

Coal seam gas is an unconventional gas resource and is an important source of gas supply in countries with large coal reserves such as Australia. While coal seam gas development in the United States has declined primarily due to the shale revolution, it is a thriving industry in Australia. The demand for clean energy in East Asia has resulted in substantial growth of the CSG industry in Australia. In 2018, Australia became the world's largest exporter of LNG: $29 \%$ of the nameplate capacity being from Australia's three east 
coast plants supplied primarily from coal seam gas resources [1]. Figure 1 shows the major CSG basins, wells and associated infrastructure including oil and gas pipelines in Australia.

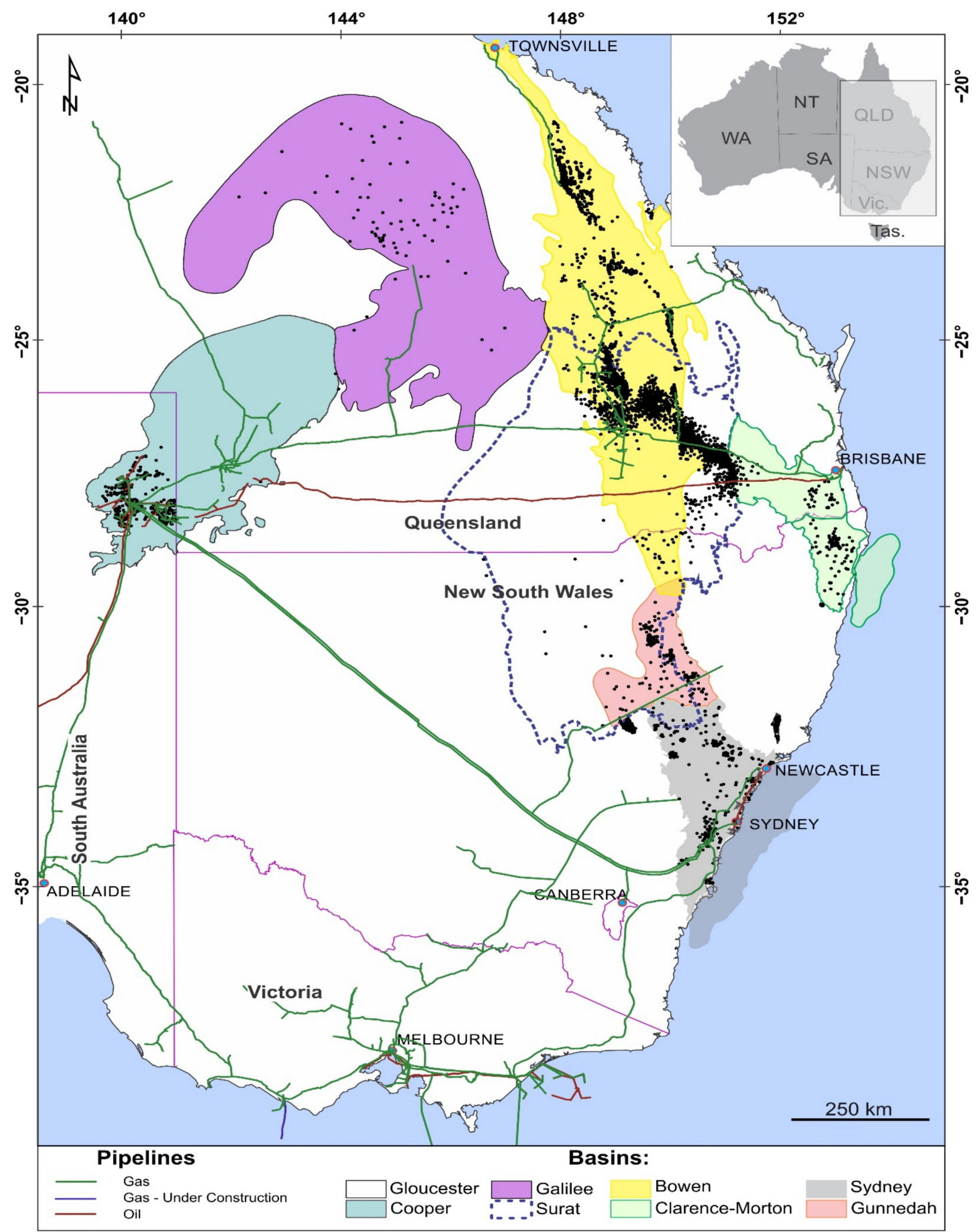

Figure 1. Location of major coal seam gas basins in eastern Australia. Wellbores (black dots) and associated infrastructure including oil and gas pipelines are also shown. 
The CSG industry is now in a new phase where the aim is to increase the export and domestic supplies and that requires significant ongoing drilling and completion activities. There are also new exploration and drilling campaigns, particularly in Queensland. In South Australia, operators are attempting to better understand unique reservoir behaviour of deep coal seams in the Cooper Basin and unlock gas resources by optimizing hydraulic fracturing and drilling multi-fractured horizontal wells [2-7]. This paper reviews the geology, in situ stress pattern, gas content and permeability of major coal seam gas basins in Australia through a review of various sources including published articles, personal communications, government reports and datasets. This paper is built on previous review papers such as a review on coalbed methane by Moore [8], relative permeability in coal by Zhang, Feng [9], modelling permeability by Pan and Connell [10] and production data analysis by Clarkson [11]. An early review paper by Miyazaki [12] discussed exploration and development of coal seam gas resources in Australia. Later, a review paper published by Towler, Firouzi [13] reviewed various aspects of CSG from history and drilling to decommissioning and regulatory compliances in Queensland. In contrast, this paper integrates coal geology and in situ stress pattern and investigates variations in gas content and permeability, both spatially and with depth, in major CSG basins in Australia. Furthermore, permeability change throughout depletion is discussed in the Bowen Basin. This allows more accurate evaluation of reserves and field development scenarios in Australian CSG basins. The other important aspect of this review paper is the investigation of deep coal seams of the Cooper Basin in South Australia as a potential gas resource.

This paper classifies the history of CSG in Australia into six key phases including pre1975, early exploration, early production, political intervention, CSG to LNG and post-2016. The history of development of deep coal seams in the Cooper Basin is reviewed separately. The geological framework of the major basins is also discussed. The in situ stress analysis and maps presented are based on information collected from CSG reservoirs and analysed by Rajabi, Tingay [14]. The information about in situ stresses can have a significant contribution to future development of CSG fields by improving hydraulic fracturing designs and mitigating wellbore stability issues. Finally, reservoir properties including gas content and permeability are discussed in the Bowen, Surat, Sydney, Gunnedah and Cooper basins and field examples are presented.

\section{History of Coal Seam Gas in Australia}

Figure 2 compares CSG production in Australia with CSG production in the US. It shows that the US production peaks in 2008 at 1966 BCF while during the same year, Australia production is only 150 BCF. The US production declines afterward and in 2016, Australia production surpasses the US production. The annual CSG production (see Figure 2) and number of wells drilled each year (see Figure 3) demonstrate six key phases in history of CSG in Australia. Although some CSG drilling has occurred in nearly all Australian mainland states, it is dominated by Queensland and New South Wales. The six phases were dominantly controlled by commerciality and overcoming technical difficulties while at the same time, working closely with local communities.

- $\quad$ Phase 1: Pre-1975

- $\quad$ Phase 2: 1975-1996 (Early Exploration)

- $\quad$ Phase 3: 1996-2005 (Early Production)

- Phase 4: 2005-2011 (Political Intervention)

- $\quad$ Phase 5: 2011-2016 (CSG to LNG)

- $\quad$ Phase 6: Post-2016 


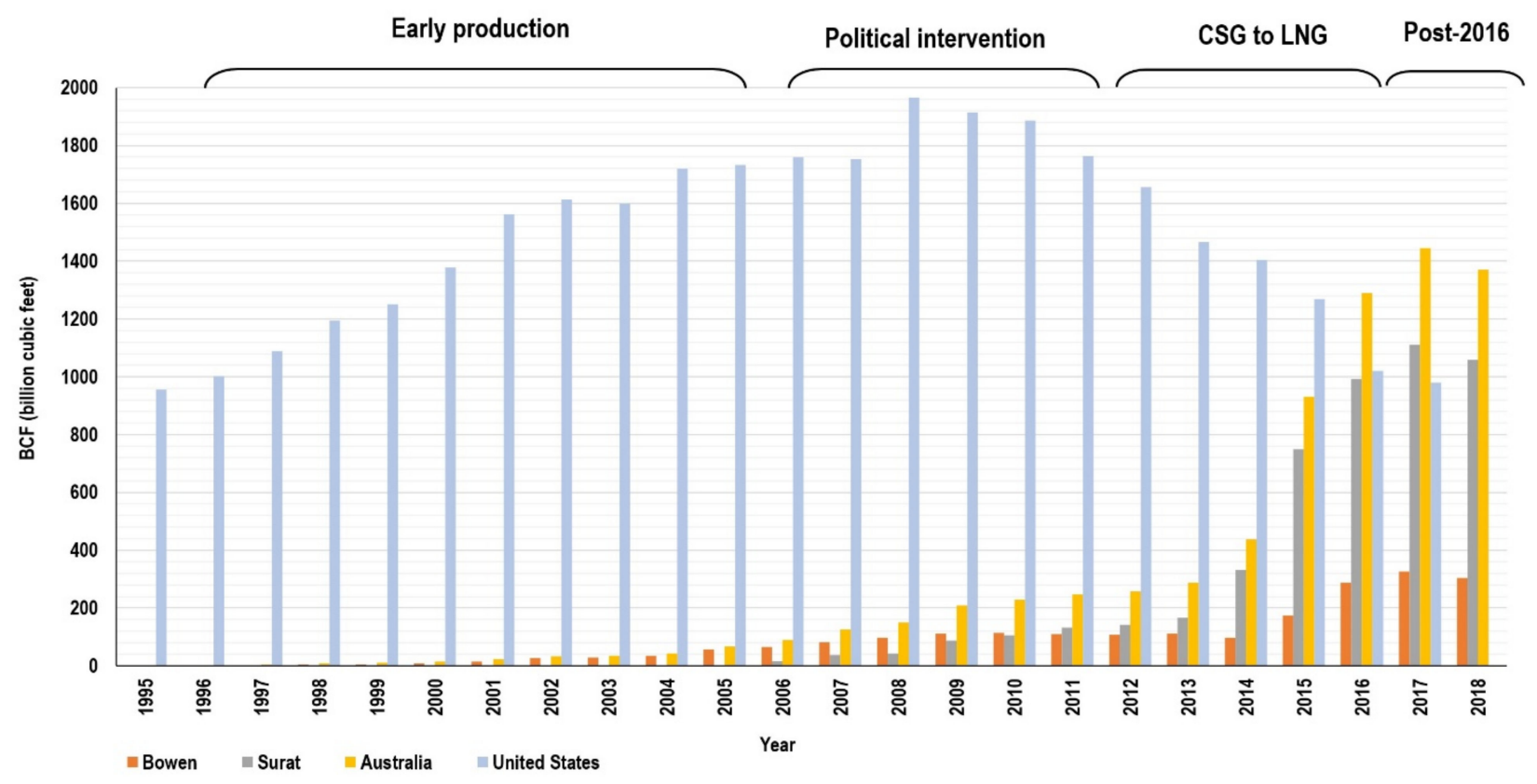

Figure 2. Annual CSG production in Australia and the US [15,16].

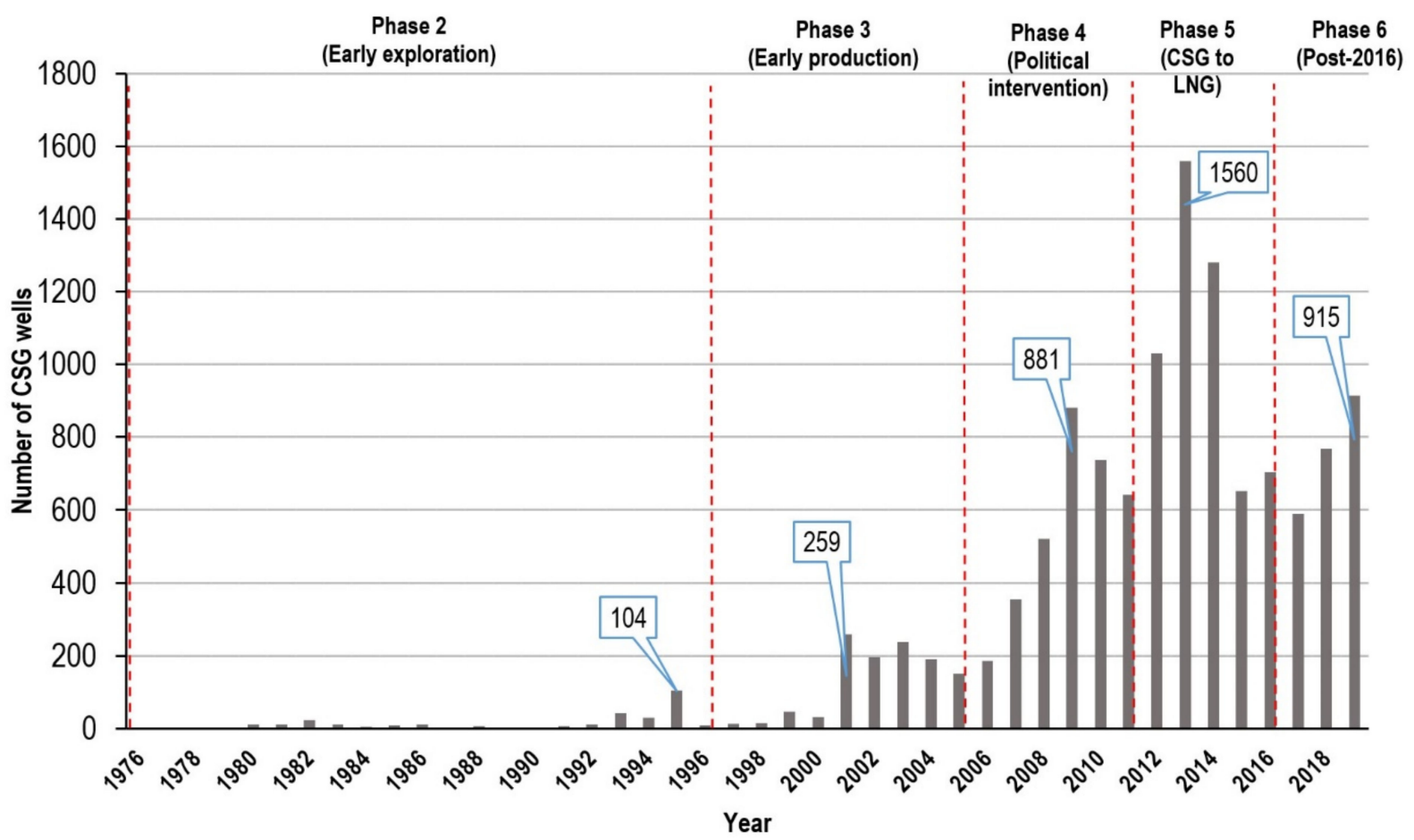

Figure 3. Number of CSG wells drilled per year in Australia since the 1980s [15].

\subsection{Phase 1: Pre-1975}

Since first being discovered by Europeans in 1797 at Coalcliff in the Illawarra of New South Wales, coal mining has been a major industry for Australia. In 2017, Australia was the world's largest exporter of coal with $32 \%$ of world trade coming from approximately 30 major mine operations, primarily in the states of Queensland and New South Wales [17]. The exported coal is primarily Permian in age and is generally high-quality bituminous coal, including both thermal and coking coal [18]. 
In the past, methane, desorbed from coal seams, has been seen a major hazard with gas explosions in underground coal mines causing major loss of life $[19,20]$. To overcome this concern, many of the underground, as well as high wall open-cut mines in Australia are degasified by drilling directional in-seam degasification wells $[19,21]$. Over time, some of this gas has been used for power generation or even domestic use. For example, Miyazaki [12] documents what was perhaps the first coal seam gas well in Australia being drilled under Sydney Harbour in the Balmain Colliery during 1944.

\subsection{Phase 2: 1975-1996 (Early Exploration)}

The history of modern coal seam gas exploration dates from 1976 when Houston Oil and Minerals drilled two wells targeting the Permian coals of the Bowen Basin in Queensland [22]. Other USA-based oil and gas companies entered the scene during the 1980 's and 1990's hoping to leverage their experience, primarily from the San Juan Basin which had just started commercial development after initial exploration having started as early as 1950 [23]. This phase focused on the Permian coals of the Bowen Basin in Queensland and the Sydney Basin in New South Wales. The cost of drilling and completion prevented economic production during this phase. By 1995, approximately 280 wells had been drilled, 55\% in Queensland and 45\% in New South Wales.

\subsection{Phase 3: 1996-2005 (Early Production)}

CSG was first produced commercially from the Permian coals of the Bowen Basin at Dawson River, near the township of Moura, in 1996. In Queensland, this development was quickly followed by other Permian coals at Fairview in 1998 and Peat/Scotia in 2002 [24]. In New South Wales, the Camden Gas Project with its Rosalind Park Gas Plant in Menangle commenced production in 2001. This project currently produces 5\% of New South Wales gas from 144 wells. One interesting insight is that these early production projects are all on the crests of major anticlines where permeabilities are improved by the structural setting. Several of the best production wells in these early projects demonstrate what could be "free gas" production, similar to conventional gas extraction, requiring little to no dewatering. During this phase, the potential of the Jurassic coals (Walloon Coal Measures) of the Surat Basin in Queensland was tested by some early exploration wells around Dalby and Chinchilla. 1280 wells had been drilled in total by 2005 with 75\% in Queensland and $25 \%$ in New South Wales.

\subsection{Phase 4-2005 to 2011 (Political Intervention)}

Recognizing the decreasing supply of conventional gas to the east coast market, and the possible impact of CSG, the Queensland Government introduced the Electricity (13\% Gas Scheme) Amendment Bill 2004 in January 2005. The bill encouraged development of new gas supply by requiring electricity retailers to supply at least $13 \%$ of their electricity from gas-fired or renewable energy sources. This requirement was increased to $15 \%$ in 2010 and $18 \%$ by 2020 [25]. This bill acted as a catalyst to increase commercial production from the Surat Basin with projects commencing in 2006 at Tipton West, Kogan and Berwyndale and ramped up rapidly. CSG production in Queensland surpassed conventional gas production in the state in 2007 and the period finished in 2011 with Surat Basin CSG production surpassing Bowen Basin CSG production. The Global Financial Crisis of 2008 had a slight impact on drilling and production but was only a minor influence.

A very different story emerged in New South Wales during this phase. Exploration had commenced in the Gunnedah, Clarence-Morton and Gloucester basins of northern New South Wales but no projects moved into commercial production. The exploration licenses in Clarence-Morton and Gloucester basins were bought back by the New South Wales government during this Phase and Phase 5 for approximately $\$ 27$ million to stop CSG exploration and production in those regions. By 2011 over 4600 CSG wells had been drilled in total with $80 \%$ being in Queensland and only $20 \%$ in New South Wales. 


\subsection{Phase 5: 2011-2016 (CSG to LNG)}

With increasing additions to reserves, CSG operators began searching for a large market for their gas. This occurred at a time when East Asian nations were searching for gas to fuel their domestic growth plans. These two forces led to the unfolding of the idea of converting CSG into LNG for export. Final investment decisions (FID) were made for these projects in 2010-2012. All three projects, which each consisted of a two-train LNG liquefaction plant, intensified drilling campaigns and gathering and compression projects, were brought to fruition during this phase (Table 1). The two-train LNG liquefaction plants were all constructed next door to each other on Curtis Island in Gladstone Harbour. This phase marks a major change and maturation of the Australian gas industry landscape with two of the projects being operated by local companies (Santos and Origin)-a first for these Australian companies in operating large-scale LNG projects [13]. As well as the massive infrastructure builds, this period of ramp-up to fill the LNG facilities led to the drilling and completion of some 6000 wells in Queensland. The low level of activity in New South Wales continued in this period with only 100 wells drilled. Hence, Queensland drilled $98 \%$ of all wells in this phase.

Table 1. CSG to LNG projects in Australia.

\begin{tabular}{|c|c|c|c|c|}
\hline LNG Facility & $\begin{array}{c}\text { Final Investment } \\
\text { Decision }\end{array}$ & $\begin{array}{c}\text { Train } 1 \\
\text { 1st Shipment }\end{array}$ & $\begin{array}{c}\text { Train } 2 \\
\text { 1st Shipment }\end{array}$ & Companies Involved \\
\hline Queensland Curtis & & & & Queensland Gas (British \\
\hline $\begin{array}{l}\text { Liquefied Natural Gas } \\
\text { (QCLNG) }\end{array}$ & 30 October 2010 & 28 December 2014 & 5 July 2015 & $\begin{array}{c}\text { Gas-now Shell); CNOOC; } \\
\text { Tokyo Gas }\end{array}$ \\
\hline Gladstone Liquefied & & & & \\
\hline $\begin{array}{l}\text { Natural Gas } \\
\text { (GLNG) }\end{array}$ & 13 January 2011 & 27 September 2015 & 25 May 2016 & Santos; Total; Petronas; Kogas \\
\hline $\begin{array}{c}\text { Australia Pacific Liquefied } \\
\text { Natural Gas } \\
\text { APLNG }\end{array}$ & 4 July 2012 & 2 January 2016 & 6 October 2016 & $\begin{array}{l}\text { Origin; ConocoPhillips; } \\
\text { Sinopec }\end{array}$ \\
\hline
\end{tabular}

\subsection{Phase 6: Post-2016}

Unlike conventional LNG projects where the development wells are drilled and simply produce through the life of the project, in CSG to LNG projects the gas stream is filled by continuous drilling of development wells. The industry has now entered the post LNG start-up phase where the requirement to continue drilling and completing thousands of wells to keep the LNG (export) and domestic gas markets serviced will be the key focus. The linking of LNG price to the international oil market has also given rise to an increase in the domestic gas price. These economic factors have facilitated the expansion of the CSG industry in Queensland and it is expected to continue for the life of the LNG projects and beyond. This means new development projects are continually coming on stream and are likely to do so for many years to come. However, as of 2019 two of the three LNG facilities were operating well below capacity and EnergyQuest has suggested that this is in part because of the projects original viability being based on estimates of Proved and Probable (2P) reserves rather than Proven (1P) reserves [26]. 2P is the standard practice for making investment decisions by the CSG industry. One of the basic assumptions at the time was high permeability discovered around the Undulla Nose in the Fairview and Spring Gully fields would be ubiquitous in Surat and Bowen basins. However, this assumption turned out to be overly optimistic. The various companies reduced many of the original $2 \mathrm{P}$ reserves, on which the LNG projects were based, but by this time, all three LNG facilities were almost completed. Figure 4 shows the $2 \mathrm{P}$ reserves in the Surat and Bowen Basins since 2005, and the 2P reserves estimates are at the highest in 2014 to 2016 and then they decline afterward. This is partly because the companies reduced many of their original $2 \mathrm{P}$ reserves that were overly optimistic. 


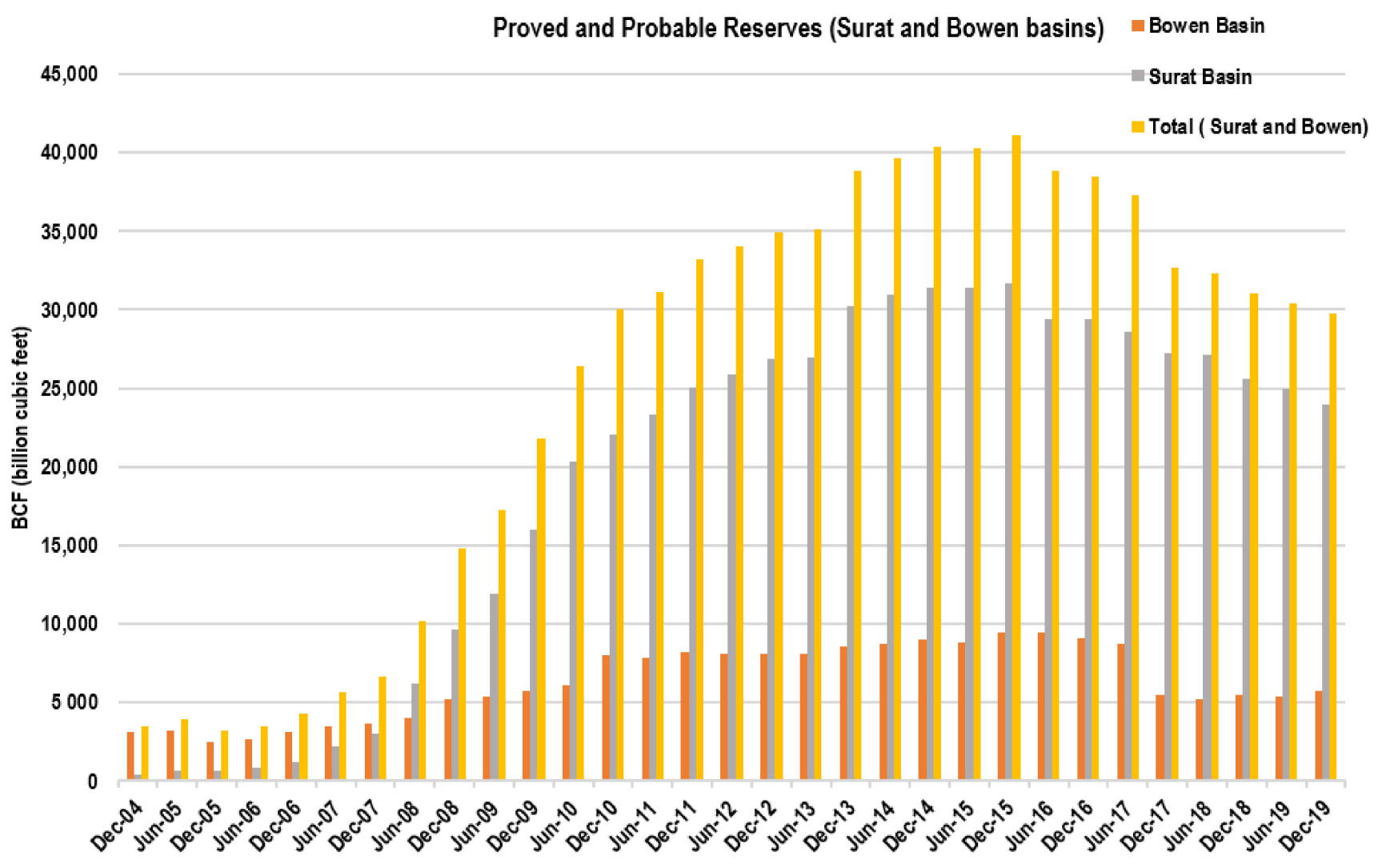

Figure 4. 2P reserves for the Surat and Bowen Basins since 2005 [27].

The opposite occurred in New South Wales, where political and environmental activism has led to no new CSG projects coming on stream. The sole New South Wales CSG project at Camden is now moving into its wind down phase and is likely to cease production in 2023. In September 2020, the Independent Planning Commission (IPC) conditionally approved the Narrabri Gas Project. It is estimated that the Narrabri Gas Project has the potential to supply half of the New South Wales's natural gas demand [28]. Geoscience Australia [18] currently estimates Australia's CSG reserves (2P) at 43 Tcf and identifies an additional $32 \mathrm{Tcf}$ of contingent resources. $92.5 \%$ of the reserves lie within the Surat and Bowen basins of Queensland.

\subsection{Development of Deep Coal Seam Gas in the Cooper Basin, South Australia}

Early assessment of deep coal seams in the Cooper Basin was conducted by analysis of gas shows in mud log records of wells intersecting deep coal seams [29], and the first desorption canister test was conducted in Dorodillo-2 in 1998 [30]. In 2007, for the first time, Patchawarra coal seams were hydraulically fractured in Moomba 77 and a gas flow rate of $\sim 0.10 \mathrm{mmscf} /$ day $\left(2832 \mathrm{~m}^{3} /\right.$ day) was reported. Figure 5 shows some of dedicated unconventional gas play wells in the Cooper Basin that were drilled to test productivity of deep coal seams and compares those with deepest producing coals in the United States and China. The deepest producing coal in the United States is from the Cameo Coal zone in the Piceance Basin (8136-8142 ft.) with a reported production rate of $0.15 \mathrm{mmscf} /$ day [31]. Hydraulically fractured dry Permian coals of the Cooper Basin show economic flowrates greater than those recorded for Cameo Coal [3]. 


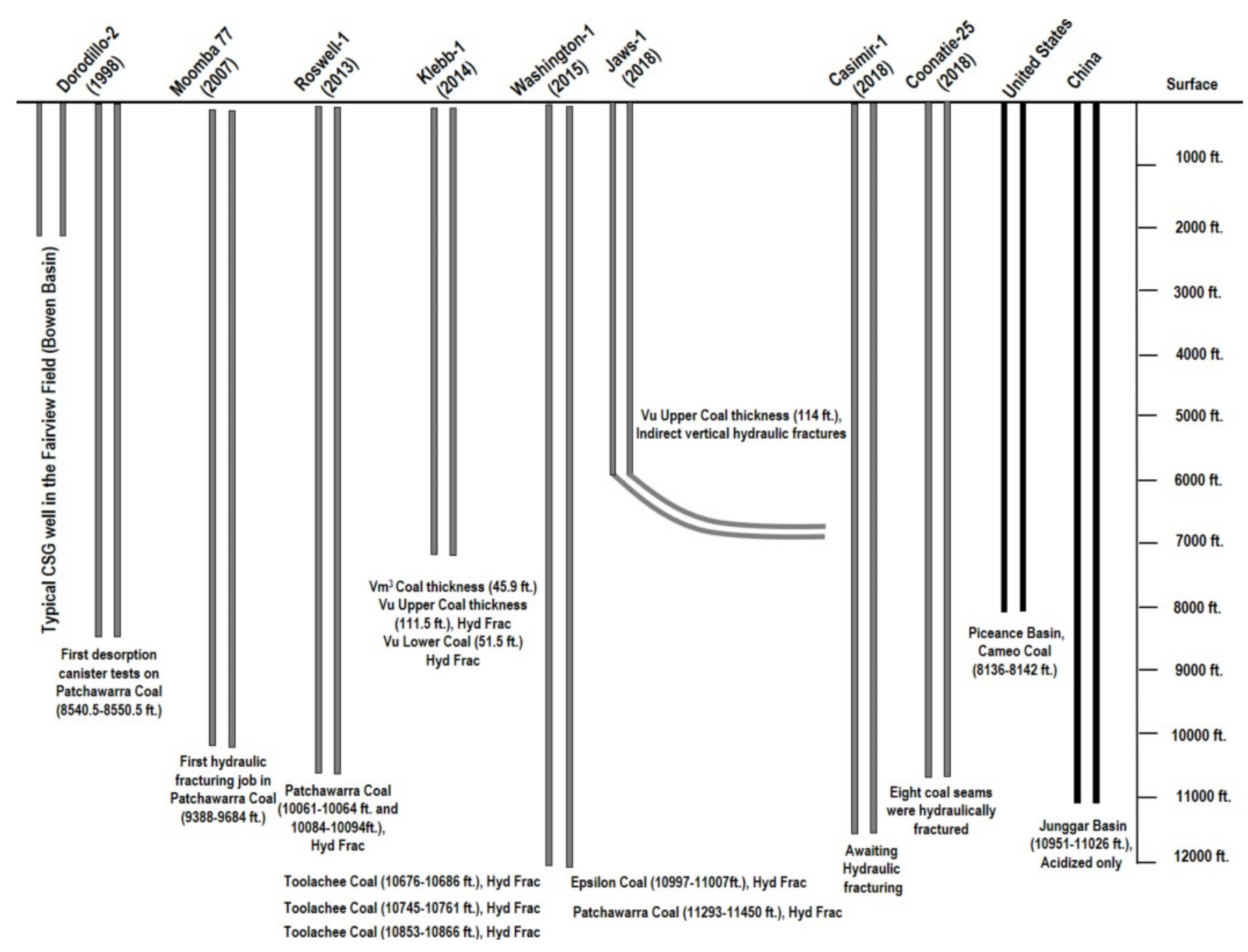

Figure 5. Dedicated deep coal wells drilled/completed in the Cooper Basin, South Australia. Moomba 77 is the first dedicated well completed in the Patchawarra coal in 2007 by the hydraulic fracturing.

In 2013, Roswell-1 was drilled and hydraulically fractured in the VC50 coal (Patchawarra coal) using cross-linked gel fracturing fluid and a higher proppant concentration than used in previous trials. This conductive fracture design resulted in a peak flow rate of $0.40 \mathrm{mmscf} /$ day. The flow results after this design change were encouraging and kick-started a year-on-year add-frac campaign in the Cooper Basin. This program involves targeting $>5 \mathrm{~m}$ thick coals for fracture stimulation in as many conventional gas development wells across the Cooper Basin as possible. Repeat production logging as a means of monitoring of production performance of deep coal seams has been critical to demonstrating long term ( $>5$ years) production, from these stimulated coal seams. To date, more than 130 add-fracs have been placed in deep coal seams of the Cooper Basin in gas development wells with overall success but variable productivity and is currently an economically viable reserve for target development since 2017 [32].

Washington-1, an exploration well drilled in 2015, was hydraulically fractured in the Toolachee, Epsilon and Patchawarra coal seams. Production logging demonstrated that gas flowed from all zones, with the deepest at $3491 \mathrm{~m}(11,199 \mathrm{ft}$.$) ; and, as such, is$ currently the deepest producing coal in the world [3]. Two further dedicated vertical wells were drilled in 2018, as a follow-up to Washington-1. Casimir-1 intersected nine coals meeting the thickness criteria but is to be fracture stimulated. The second well in the 2018 campaign, Coonatie-25, accessed both coal and conventional tight sand. Eight coal seams were hydraulically fractured with the VC50 (mid-Patchawarra coal) delivering the highest rate on test of $0.48 \mathrm{mmscf} /$ day. Coonatie-25 has been on production since March 2018.

The Southern Cooper Basin Gas Project, located $100 \mathrm{~km}$ south of Moomba, targets deep coal seams in the Patchawarra Formation at the depth of the $2000 \mathrm{~m}$. In late 2017, the Klebb pilot that includes four wells was claimed as a technical success, but the wells did 
not achieve commercial gas rates [33]. In 2018, Jaws-1, a horizontal multi-fractured well, was planned to drill in the Vu Upper Coal, however the well encountered wellbore stability issues while drilling and hence plugged and side-tracked and drilling continued below the $\mathrm{Vu}$ Upper coal for the purpose of better stability. Indirect vertical fracture completion (IVFC) technique was utilized to complete the well in the Vu Upper coal. Seven vertical fractures were placed in the Jaws-1, six of which initiated outside of the target formation [2]. In December 2020, Jaws-1 was shut down because gas production did not reach to commercial rates and the Klebb pilot project will be ceased in 2021 [34].

\section{Geological Framework of Coal Deposits and Coal Seam Gas Resources in Australia}

Major accumulations of coal in Australia are present in Palaeozoic, Mesozoic and Cenozoic strata $[35,36]$. Along with coal seam gas, some of these coals have long been mined as fuel for power plants and steel production. Geological factors such as coal rank and hydrogeology are important in making favourable conditions for gas production [8,37-45]. These, in turn, are controlled by the geologic history of each basin, including burial, uplift, tectonic deformation, and variations in heat flow through time. In this section, six basins with CSG resources are described.

\subsection{Bowen Basin}

The Permian-Triassic-Bowen Basin in Queensland is one of the world's major coal basins [46-48]. It is the northern sector of the larger Sydney-Gunnedah-Bowen Basin, which is a composite structural basin that stretches from southern New South Wales to central Queensland (see Figure 1) [49]. The basin has up to $10 \mathrm{~km}$ of sedimentary fill and has a complex tectonic and structural history [50-52]. It began as a back arc basin in the early Permian and was followed by a phase of thermal subsidence in the early late Permian [53]. In the late Permian, a foreland basin developed together with extensive coal accumulations $[54,55]$. The basin was later subject to a major compressive deformation and uplift episode in the Middle-Late Triassic and intruded by igneous bodies in the Cretaceous, which influenced the preservation, distribution, rank and gas content of coals [49]. The basin has significant CSG resources in addition to large reserves of metallurgical and thermal coal $[13,22,40,52,53,56-58]$. CSG is produced in the Moranbah and Moura regions (northern Bowen Basin), in the Injune area (western Bowen Basin) and in the Wandoan area (eastern Bowen Basin) $[24,40,53,59,60]$. Three stratigraphic units are major targets for CSG production in the Bowen Basin [53] including the Moranbah Coal Measures/German Creek Formation at the Moranbah Gas Project; the Baralaba Coal Measures at the Moura Gas Project, and the Bandanna Formation at the Fairview and Spring Gully Projects [13,46,57,61,62]. A summary of these stratigraphic units is provided in Table 2.

The most significant CSG project in the Bowen Basin is the Fairview Field, associated with the delta-top/fluvial upper Permian Bandanna Formation [53]. The field is located on an anticline associated with the Comet Ridge, which enhances the permeability of the coal beds to $>50 \mathrm{mD}$ [53]. In this locality, the Bandanna Formation is between $500-880 \mathrm{~m}$ and contains three coal seams that have a total net thickness of $10 \mathrm{~m}$ [65].

The thick and laterally continuous nature of the coal seams have contributed to the viability of CSG plays in the Bowen Basin. These coals have a wide range of ranks, vitrinite content and gas content but vitrinite reflectance is generally $>0.9 \%$ and vitrinite content averages $\sim 70 \%[12,66-68]$. Variations in rank are attributed to the basin's complex tectonic and burial history, with gas sweet spots associated with large anticlinal structures, including the Burunga Anticline, where there is an increase in the permeability of coals (up to $100 \mathrm{mD}$ ) [40]. The majority of CSG in the Bowen Basin is predominantly of a thermogenic origin (associated with deep burial depths) with a small biogenic component [13]. 
Table 2. Summary of key geological characteristics of CSG-bearing units in the Bowen Basin $[22,40,49,53,57,63,64]$.

\begin{tabular}{|c|c|c|c|c|c|c|c|c|}
\hline $\begin{array}{l}\text { Stratigraphic } \\
\text { Unit and } \\
\text { Environment of } \\
\text { Deposition }\end{array}$ & Age & $\begin{array}{l}\text { Thickness } \\
\text { (m) }\end{array}$ & $\begin{array}{l}\text { Coal Bed } \\
\text { Thickness } \\
(\mathrm{m})\end{array}$ & $\begin{array}{l}\text { Lateral } \\
\text { Continuity } \\
(\mathbf{k m})\end{array}$ & Rank \% $\mathbf{R}_{\mathbf{o}}$ & Composition & $\begin{array}{l}\text { Total } \\
\text { Moisture } \\
\text { Content } \\
(w t \%)\end{array}$ & $\begin{array}{l}\text { Ash } \\
\text { Content } \\
(\%)\end{array}$ \\
\hline $\begin{array}{l}\text { Moranbah Coal } \\
\text { Mea- } \\
\text { sures/German } \\
\text { Creek Formation } \\
\text { (Deltaic) }\end{array}$ & $\begin{array}{l}\text { Permian } \\
\text { (Lopingian) }\end{array}$ & $100-800$ & $\begin{array}{l}5-8, \text { net coal } \\
\text { thickness } 15\end{array}$ & $\begin{array}{c}\text { Split and } \\
\text { coalesce over } \\
250\end{array}$ & $0.6-3.5$ & $\begin{array}{c}55-90 \% \text { vitrinite, } \\
<1 \% \text { liptinite, } \\
9-39 \% \text { inertinite }\end{array}$ & $8.0-11$ & $5-15$ \\
\hline $\begin{array}{c}\text { Rangal Coal } \\
\text { Measures } \\
\text { (Fluvio-deltaic) }\end{array}$ & $\begin{array}{l}\text { Permian } \\
\text { (Lopingian) }\end{array}$ & $25-240$ & $\begin{array}{c}1-7.7, \text { net } \\
\text { coal } \\
\text { thickness } \\
8\end{array}$ & $>25$ & $0.6-2.6$ & $\begin{array}{l}46-65 \% \text { vitrinite, } \\
<1-3 \% \text { liptinite, } \\
3-53 \% \text { inertinite }\end{array}$ & $8.0-12$ & $6.9-10$ \\
\hline $\begin{array}{c}\text { Baralaba Coal } \\
\text { Measures/ } \\
\text { Bandanna } \\
\text { Formation } \\
\text { (Fluvio-deltaic) }\end{array}$ & $\begin{array}{c}\text { Permian } \\
\text { (Lopingian) }\end{array}$ & $9-556$ & $\begin{array}{c}\text { 6- > } 30 \mathrm{~m} \text {, net } \\
\text { coal } \\
\text { thickness } 30\end{array}$ & $\begin{array}{l}\text { High degree } \\
\text { of lateral } \\
\text { continuity }\end{array}$ & $0.6-2.6$ & $\begin{array}{l}30-70 \% \text { vitrinite, } \\
<1-2 \% \text { liptinite, } \\
\text { up to } 35 \% \\
\text { inertinite }\end{array}$ & $8-11$ & $7-16$ \\
\hline
\end{tabular}

\subsection{Sydney-Gunnedah Basins}

The Late Carboniferous to Triassic Sydney-Gunnedah basins of New South Wales is the southern part of the Sydney-Gunnedah-Bowen Basin (see Figure 1) [36]. The Sydney and Gunnedah basins share a similar complex tectonic history and contain up to $6 \mathrm{~km}$ of sedimentary infill [69]. The basins evolved in several phases from the late Carboniferous to the Middle Triassic [70]. The origins of the basins are uncertain with crustal extension [71] and volcanic rift models [72] proposed. A foreland basin phase associated with prevalent volcanic activity then ensued during the Permian [70]. The basin was subject to a phase of compressional tectonics in the Late Permian [70]. In the late Triassic, sedimentation ended in the basin due to an episode of major compressive deformation [73]. Further episodes of deformation occurred in the Late Cretaceous and the Tertiary [70]. Similar to the Bowen Basin, the Sydney and Gunnedah basins host significant reserves of metallurgical and thermal coal [74] but CSG activity occurs only on a limited scale in the region. CSG wells are predominately located in the Camden Field in the southern Sydney Basin [75] with some located on prospects in the Hunter Coalfield in the northern Sydney Basin [76]. The Narrabri Gas Project in the Gunnedah Basin is thought to be highly prospective [77]. Two stratigraphic units are targets for CSG production in the Sydney-Gunnedah basins and are summarised in Table 3.

The southern Sydney Basin has a cumulative reservoir thickness ( $>20 \mathrm{~m}$ of coal) and thin interburden between productive horizons ( $<200 \mathrm{~m})$ [70]. Gas consists of up to $95 \%$ methane and is of thermogenic and biogenic origin but on a local scale has been influenced by magmatism [83]. There is a lack of productive aquifers in the area and a well-developed cleat system enhances permeability $(1-30 \mathrm{mD})[70]$.

In the Gunnedah Basin, cumulative coal thickness is greater than $80 \mathrm{~m}$ [70]. Igneous intrusions play a significant part in the viability of CSG plays. The intrusions take the form of Late Triassic-Early Cretaceous alkali basalt and trachyte associations, and a Tertiary flood basalt association [84]. Sills and dykes typically have a detrimental effect, such as dispelling coal seam gases, reducing permeability, and replacing methane with carbon dioxide [77,81]. However, intrusions may also locally increase coal rank into the optimal thermogenic gas generation window as well as acting as impermeable seals to gas flow [77]. Seams adjacent to the intrusions have vitrinite reflectance values as high as $11 \% \mathrm{Rv} \max$ [77]. 
Table 3. Summary of key geological characteristics of CSG-bearing units in the Sydney-Gunnedah Basin [70,73,78-82].

\begin{tabular}{|c|c|c|c|c|c|c|c|c|}
\hline $\begin{array}{l}\text { Stratigraphic } \\
\text { Unit and } \\
\text { Environment of } \\
\text { Deposition }\end{array}$ & Age & $\begin{array}{l}\text { Thickness } \\
\text { (m) }\end{array}$ & $\begin{array}{l}\text { Coal Bed } \\
\text { Thickness } \\
(\mathrm{m})\end{array}$ & $\begin{array}{c}\text { Lateral } \\
\text { Continuity } \\
(\mathbf{k m})\end{array}$ & Rank \% $\mathbf{R}_{\mathrm{o}}$ & Composition & $\begin{array}{l}\text { Total } \\
\text { Moisture } \\
\text { Content } \\
\text { (wt } \%)\end{array}$ & $\begin{array}{l}\text { Ash } \\
\text { Content } \\
(\%)\end{array}$ \\
\hline $\begin{array}{c}\text { Illawarra Coal } \\
\text { Measures } \\
\text { (southern Sydney } \\
\text { Basin) } \\
\text { (Fluvio-deltaic)) }\end{array}$ & $\begin{array}{c}\text { Permian } \\
\text { (Lopingian) }\end{array}$ & 520 & $\begin{array}{l}2-5, \text { net coal } \\
\text { thickness in } \\
\text { excess of } 20\end{array}$ & $\begin{array}{l}\text { High degree } \\
\text { of lateral } \\
\text { continuity }\end{array}$ & $0.8-1.43$ & $\begin{array}{l}30-79 \% \text { vitrinite, } \\
<1-7 \% \text { liptinite, } \\
\text { inertinite } 1-43 \%\end{array}$ & $0.9-2.0$ & $8.2-16.8$ \\
\hline $\begin{array}{l}\text { Hoskissons Coal } \\
\text { Member, Black } \\
\text { Jack Group } \\
\text { (Gunnedah } \\
\text { Basin) } \\
\text { (Back barrier) }\end{array}$ & $\begin{array}{c}\text { Permian } \\
\text { (Lopingian) }\end{array}$ & $2.4-18 \mathrm{~m}$ & $<1.17$ & $\begin{array}{l}\text { Laterally } \\
\text { extensive }\end{array}$ & $0.6-5.3$ & $\begin{array}{c}8-44 \% \text { vitrinite, } \\
2-5 \% \text { liptinite, } \\
53-87 \% \text { inertinite }\end{array}$ & $2.5-5.7$ & $9-21$ \\
\hline
\end{tabular}

\subsection{Surat Basin}

The Triassic-Cretaceous Surat Basin overlies the southern part of the Bowen Basin and contains Australia's largest CSG resource [85]. The Surat Basin is a large intracratonic basin with up to $2.5 \mathrm{~km}$ of sedimentary infill (see Figure 1) [53]. Three mechanisms have been proposed to explain the tectonic evolution of the basin including thermal subsidence [86], dynamic platform tilting [87] and intraplate rifting [88]. The basin was uplifted during the Late Jurassic and again in the mid-Cretaceous, leading to the erosion of the eastern part of the basin [89,90]. The major CSG producing interval is the Middle to Upper Jurassic Walloon Coal Measures of the northern Surat Basin. Walloon Coal Measures are divided into five distinct formations including the sandstone dominated Durabilla Formation, Taroom Coal Measures, relatively coal barren Tangalooma sandstone, Upper Juandah Coal Measures and Lower Juandah Coal Measures [91-94]. The depositional environment of the Walloon Coal Measures has been investigated in the literature and different environments such as fluvio-lacustrine, composite meandering to anastomosing fluvial system and waterlogged alluvial plain have been suggested [85,91,95-98].

Coal beds are thin: between $1 \mathrm{~cm}$ and $30 \mathrm{~cm}$ thick which have limited lateral continuity with individual beds rarely traced in the subsurface for more than $5 \mathrm{~km}$ [99]. Vitrinite content is between 62 and $90 \%$, liptinite content is between 8 and $33 \%$ and inertinite content is $~ 1 \%$ [100]. The ash content varies substantially with a minimum of $5.1 \%$ and moisture contents up to $20.7 \mathrm{wt} \%$ [100]. The majority of gas production is of a biogenic origin [101].

\subsection{Cooper Basin}

The intracratonic Late Carboniferous-Triassic Cooper Basin in South Australia and Queensland is Australia's largest onshore oil and gas province (see Figure 1) and has been producing conventional resources for over 50 years [102]. Cooling of heat flow following granite emplacement in the Carboniferous led to rapid basin subsidence creating the Cooper Basin and later infilled by $2.5 \mathrm{~km}$ of sediments [103]. The basin experienced three episodes of uplift during the Permian caused by plate margin stresses in the east [104]. An intraplate east-west compressional regime brought an end to sedimentation in the basin during the Triassic [105]. The basin is overlain by the Jurassic-Cretaceous Eromanga Basin and the Cenozoic Lake Eyre Basin [103]. The stratigraphic unit with the most CSG potential in the basin is the Lower Permian Patchawarra Formation which was deposited in a fluvio-lacustrine setting $[104,106]$. The unit is $250-500 \mathrm{~m}$ thick with coal seams between 0.3 and $60 \mathrm{~m}$ in thickness $[103,106]$. Some seams cover an area of up to $1500 \mathrm{~km}^{2}$ [106]. The coals consist predominately of inertinite (45-86\%) [103]. Vitrinite content of the coals is mostly between $3 \%$ and $20 \%$ with liptinite content mostly between $1 \%$ and $15 \%$ [107]. Coals are bituminous in rank $\left(0.8 \%\right.$ to $\left.1.8 \% \mathrm{R}_{\mathrm{o}}\right)$ with low moisture contents (average $3.33 \mathrm{wt} \%$ ) and an average ash content of 3.66\% [108]. The VC50 (5-23 m thick), Vm3 (19.5-24 m thick) and the $\mathrm{Vu}(17-45 \mathrm{~m}$ thick) coals are the most prospective for potential CSG activities in the 
basin [109]. The VC50 coal is the thickest in the basin (5-23 m), with high lateral continuity $(>8 \mathrm{~km})$ and significant micro-porosity $(4 \%$ to $9 \%)[4,109]$. Other coals with CSG potential in the basin are in the Permian Epsilon (seams up to $29 \mathrm{~m}$ thick) and Daralingie formations (seams up to $3 \mathrm{~m}$ thick) [108].

\subsection{Gloucester Basin}

The early Permian Gloucester Basin is a small remnant inter-arc basin located in New South Wales (see Figure 1) [110]. The basin has a complex geological history starting with early to late Permian extension [111]. A late Permian episode of compression led to basin inversion [111]. The Waukivory Pilot Project (now closed) and the Gloucester Gas Project (which reached the development phase before being cancelled) were the only CSG projects to have commenced in the basin [111].

The Lower Permian Gloucester Coal Measures, deposited in a deltaic environment, is the primary target for CSG production [111]. As described by Hughes [110] and Ward, Bocking [112], the formation is up to $2 \mathrm{~km}$ thick with coal seams between 5 and $30 \mathrm{~m}$ in thickness. The coals are characterised by considerable lateral splitting over short distances [113]. The coals are composed of between $45-50 \%$ vitrinite with high amounts of inertinite [114].

\section{In Situ Stress Pattern in the Australian Coal Seam Gas Basins}

The in situ stress in Australian CSG reservoirs is complex and highly variable and hence it plays an important role in gas production [81,115-120]. In this section, the in situ stress pattern of the Australian coal seam gas basins are reviewed followed by their applications in coal seam gas exploration and production.

Rajabi, Tingay [14] have developed the in situ stress map of Australia with significant stress information from CSG basins. The regional pattern of $S_{\mathrm{Hmax}}$ orientation in the Australian continent can be explained by four regional trends. As indicated in Figure 6, the $S_{\text {Hmax }}$ orientation in south-eastern Australia is NW-SE and rotates to approximately ENE-WSW in most of eastern Australia (including coal seam gas basins). The $\mathrm{S}_{\mathrm{Hmax}}$ in the northern and north-eastern Australia, including northern part of the Bowen Basin, is NE-SW. A predominant E-W $S_{\text {Hmax }}$ orientation exists in many parts of Western Australia and South Australia (including the Cooper-Eromanga Basins) [14].

Several studies have been conducted on the in situ stress pattern of eastern Australia with particular emphasis on the CSG basins [115-117,119-121]. Statistical analyses of stress data resulted in the classification of nine stress provinces in the Australian CSG basins (Table 4) $[14,122]$. As shown in Figure 7 and Table 4, the mean $S_{H \max }$ orientation in northern part of the Bowen Basin is $032^{\circ}$, which is consistent with regional $S_{\text {Hmax }}$ orientation in most part of the northern Australia. Southern part of the Bowen Basin and the entire Surat Basin in Queensland have a regional $S_{\mathrm{Hmax}}$ orientation of $065^{\circ}$. The mean $\mathrm{S}_{\mathrm{Hmax}}$ orientation in New South Wales CSG basins has a regional NE-SW trend but there is significant variability similar to other basins across Australia. For example, the mean $\mathrm{S}_{\mathrm{Hmax}}$ orientation in the Clarence-Moreton Basin is $069^{\circ}$ which rotates to $057^{\circ}$ and $034^{\circ}$ in the Gunnedah and Gloucester basins, respectively. The Sydney Basin in New South Wales, which is the southern part of the Sydney-Gunnedah-Bowen Basin, shows two regional $S_{H \max }$ trend including $041^{\circ}$ and $065^{\circ}$ in the southern and northern part of the basin, respectively. In contrast with all CSG basins in eastern Australia that show a regional trend of NE-SW orientation for the $\mathrm{S}_{\mathrm{Hmax}}$, in the Cooper, Eromanga and Galilee basins in central Australia are characterised by a regional E-W orientation (Figure 7 and Table 4). 


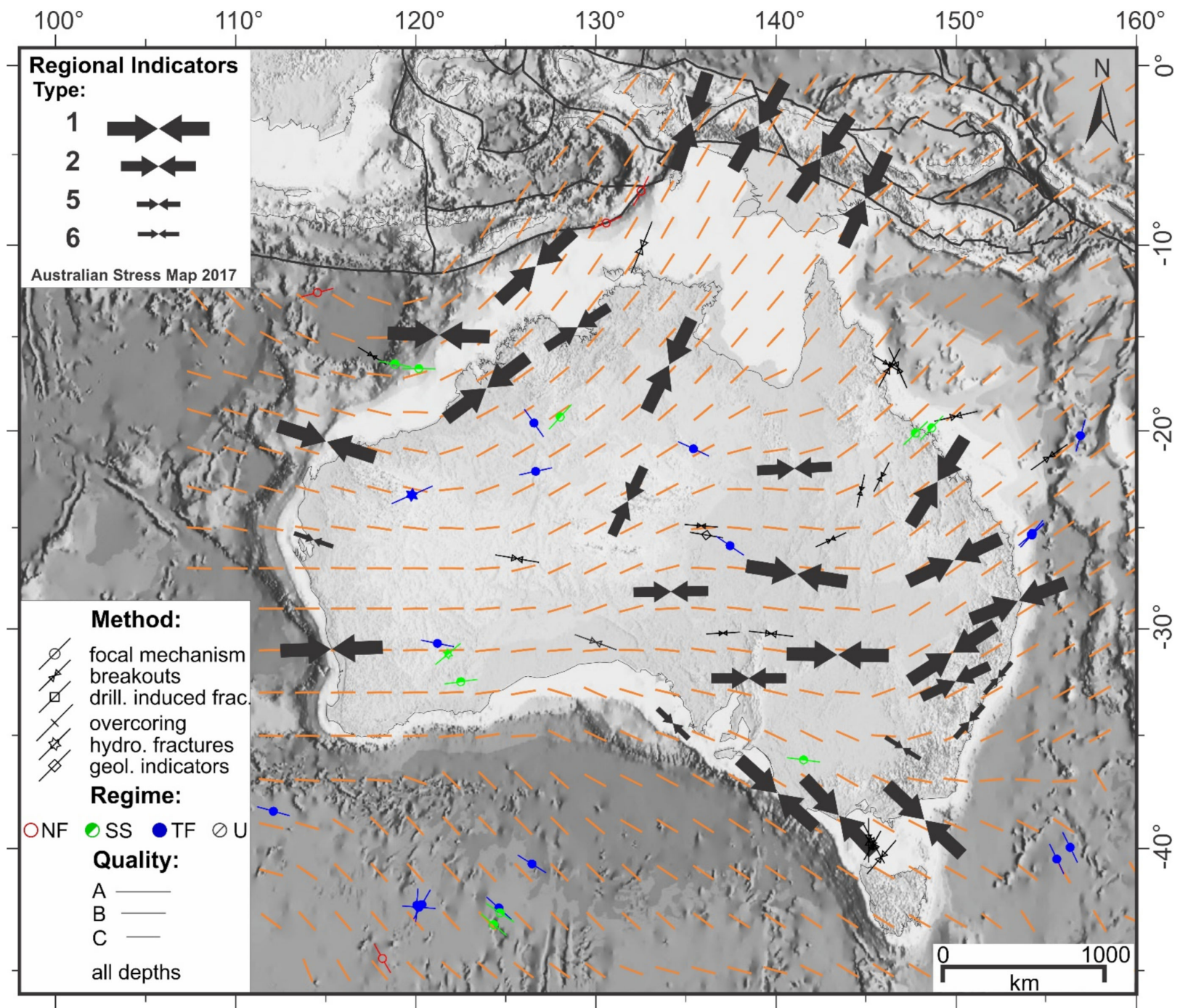

Figure 6. Stress provinces across the Australian continent [14]. The orange lines show the smoothed pattern of maximum horizontal stress $\left(\mathrm{S}_{\mathrm{Hmax}}\right)$ that demonstrate the variability of $\mathrm{S}_{\mathrm{Hmax}}$ across the Australian continent.

In addition to stress variability from basin to basin, large stress perturbations, at basin scale, have been reported in each of the CSG basins. These $S_{\text {Hmax }}$ variabilities can be seen on the maps (Figure 7) and also are represented by high standard deviations in mean $\mathrm{S}_{\mathrm{Hmax}}$ orientation of each stress provinces (Table 4). Basin scale rotation of stresses in CSG basins has been explained by major geological structures and complex tectonic deformation of each basin. This complex tectonic history in each basin has resulted in extensive faulting, folding and juxtaposition of different formations [53], which are responsible for basin scale rotation of stress. The stress variations in the Bowen, Surat, Gunnedah, Clarence-Moreton, Sydney and Gloucester basins are because of the presence of geological structures such as faults, lithological contrasts and basement structures that are documented in the literature (see Figure 7) [14,81,115,116,119,120,122].

Analysis of high-resolution wellbore image log data in CSG wells have provided the opportunity to further investigate the in situ stress pattern at small scales (i.e., wellbore scale; 1-1000 m). The localised stress variations that occur in the presence of small-scale geological features and localised elastic rock property contrasts play a critical role in subsurface fluid flow in coal seams $[81,117,123]$. In the detailed analysis of borehole image logs in the Gunnedah Basin, Rajabi, Tingay [121] observed that geological structures, including faults, fracture and magmatic intrusions, strongly perturbed stresses in the region. Following this study, Salmachi, Rajabi [81] investigated the effect of magmatic 
intrusions on reservoir characteristics of the Hoskissons coal seams in the Gunnedah Basin by the integration of borehole image log interpretation and drill stem test data analysis. In one of the studied wells (Lake Goran 1) with the thickest intrusion $(126 \mathrm{~m})$, despite the presence of open fractures, very low permeability was measured. In situ stress analysis in Lake Goran 1 shows large $S_{\text {Hmax }}$ perturbation with depth (standard deviation of $\sim 40^{\circ}$ ). It was interpreted that large stress perturbation along this well may have impaired fracture connectivity resulting in low permeability [81].

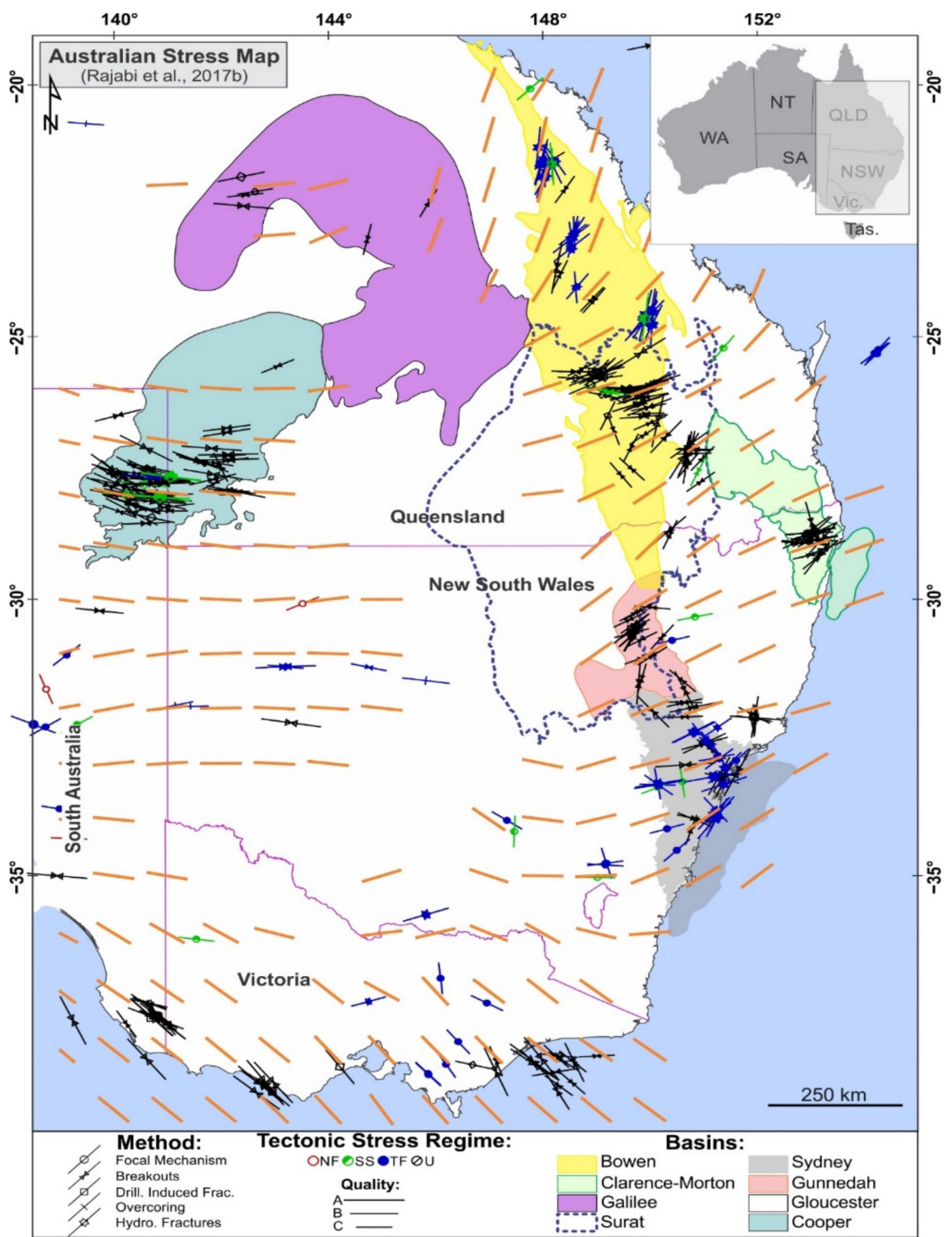

Figure 7. In situ stress pattern of major coal seam gas basins in eastern and central Australia and the smoothed stress pattern (orange lines) showing the regional orientation of maximum horizontal stress [14]. Different symbols show the method of measurement for stress data including focal mechanism solution of earthquakes, borehole breakouts, drilling induced fractures, over coring, and hydraulic fracturing measurements (see [14] for the details of each method). Different colours indicate different tectonic stress regime (NF, normal; SS, strike-slip; TF, thrust; U, unknown). The length of the lines for each stress indicator illustrates the quality of stress orientation based on the World Stress Map ranking criteria [124]. 
Table 4. Mean $\mathrm{S}_{\mathrm{Hmax}}$ orientation in different Australian CSG basins [14]. A-C refers to available stress data records in each basin based on the World Stress Map quality ranking criteria [124].

\begin{tabular}{cccc}
\hline Province & $\begin{array}{c}\text { Number of A-C } \\
\text { Quality Data }\end{array}$ & $\begin{array}{c}\text { Mean } \text { Smax }_{\text {Hmientation }} \text { Orion } \\
\text { (Degree from North) }\end{array}$ & Standard Deviation \\
\hline Bowen-Surat 1 & 64 & $032^{\circ}$ & $30^{\circ}$ \\
Bowen-Surat 2 & 52 & $065^{\circ}$ & $33^{\circ}$ \\
Clarence-Moreton & 21 & $069^{\circ}$ & $23^{\circ}$ \\
Cooper-Eromanga & 78 & $099^{\circ}$ & $14^{\circ}$ \\
Galilee-Eromanga & 5 & $087^{\circ}$ & $8^{\circ}$ \\
Gloucester & 5 & $034^{\circ}$ & $52^{\circ}$ \\
Gunnedah & 30 & $057^{\circ}$ & $33^{\circ}$ \\
North Sydney & 32 & $065^{\circ}$ & $40^{\circ}$ \\
South Sydney & 11 & $041^{\circ}$ & $35^{\circ}$ \\
\hline
\end{tabular}

In addition to the $\mathrm{S}_{\mathrm{Hmax}}$ orientation, the analyses of stress magnitudes have also shown changes in stress regime spatially and with depth [14,115,120,122,125]. For example, shallow over-coring and hydraulic fracturing measurements in the Sydney Basin in New South Wales and Bowen Basin in Queensland show a prevailing reverse stress regime with some changes to the strike-slip regime $[14,126]$. Recent analysis of wellbore data in CSG basins in the Bowen-Surat [120] and Cooper [125] basins have highlighted the changes of stress magnitude with depth. This variability of stress magnitudes with depth has also been predicted by 3D geomechanical-numerical model of Australia. There is a prevailing reverse stress regime at shallower depths of the coal seam gas basins of Australia that changes to the strike-slip regime and in some locations to normal stress regime [122].

\section{Applications of In Situ Stresses in Coal Seam Gas Exploration and Production}

It has been demonstrated that the in situ stresses significantly control the fluid flow pattern in the fractured reservoirs because those fractures which oriented parallel (or at $\sim 30^{\circ}$ ) to the intermediate or maximum principal stress are more susceptible to tensile or shear failure [127]. In the Andersonian stress regime classification, the $\mathrm{S}_{\mathrm{Hmax}}$ is always the intermediate or maximum principal stress and, therefore, it is generally observed that fractures that are sub-parallel to the orientation of $S_{H \max }$ typically facilitate fluid flow and hydrocarbon extraction [127]. Coal seam gas reservoirs generally have low matrix permeability and coal cleats play a critical role in permeability and fluid flow in these reservoirs $[96,128,129]$. Therefore, the variable in situ stress pattern can significantly control the fluid flow within the cleat system. Mukherjee, Rajabi [117], investigated the interaction of subsurface fractures, orientation of $S_{\mathrm{Hmax}}$ and permeability data in 33 CSG wells penetrated into the Walloon Coal Measures, in the eastern part of the Surat Basin, Queensland. The results revealed that there are high $S_{\mathrm{Hmax}}$ perturbations, from well to well, due to geological structures affecting permeability. Interestingly, high permeability zones are located where $S_{\text {Hmax }}$ rotates from the regional trend [117].

The stability of wells is also influenced by the geomechanical parameters such as orientation and magnitudes of in situ stresses. Drilling deviated and horizontal wells is challenging where stress pattern is complex $[119,130]$. The state of in situ stresses has been also explained as an influencing parameter in hydraulic fracture design in unconventional reservoirs such as coal seam gas and shale gas reservoirs [119-121,129,131]. This issue is particularly important for CSG basins in Australia because of significant stress perturbations in the major coal seam gas basins. These variable stress patterns have caused complex fracturing stimulations during hydraulic fracturing tests in the CSG basins $[116,120]$. For example, Flottmann, Brooke-Barnett [116], investigated the relationship between in situ stress, natural fractures and propagation of hydraulic fractures in the Surat Basin. In particular, they reported significant variations in both stress orientation and stress regime, which resulted in the propagation of complex hydraulic fractures. Analysis of micro-seismic and tilt-meter results by Flottmann, Brooke-Barnett [116] revealed planar hydraulic fracture 
propagation in areas with high differential stresses (in reverse stress regime). In areas with low differential stresses, both stresses and pre-existing natural fractures control the propagation of hydraulic fractures resulting in more complex hydraulic fracture patterns. Moreover, in another study conducted by Rahman, Suarez [118], many unsuccessful hydraulic fracturing treatments, due to the presence of complex in situ stress fields, in the Australian CSG fields have been discussed.

The variable stress state has numerous implications for CSG exploration and production in eastern Australia $[37,132]$. Therefore, it is necessary to carry out a comprehensive analysis of present-day stress to determine the regional and local-scale stress perturbations for further decisions such as horizontal drilling and hydraulic fracture design.

\section{Gas Content and Permeability in Major Australian CSG Basins}

Gas content, gas saturation and permeability are critical reservoir attributes that influence the economics of any CSG project [8]. In Australia, the procedure used to measure gas content follows the Australian Standard (AS 3980:2016) "determination of gas content of coal and carbonaceous material-direct desorption method" (historical editions: AS 3980-1999, AS 39801991). Total gas content is the summation of three components; lost gas $\left(Q_{1}\right)$, desorbed gas $\left(Q_{2}\right)$ and residual gas $\left(Q_{3}\right)$. Lost gas volume depends on several factors including how quickly a sample is retrieved and placed within the desorption canister, coal diffusion coefficient and diffusion distances (cleat spacing), drilling fluid and free gas volume [20,133]. Gas content is heterogeneous spatially and even vertically within an individual coal seam in Australia. This is consistent with observations in North American coal seams reported by Pashin [134], Pashin [135] and Scott [44]. The primary reasons for these variabilities are interrelated factors including coal rank and depth, thermal effect of magmatic intrusions, hydrogeology and sealing capability of overlying formations $[44,77,81,136,137]$.

High gas production may not be achieved even from extremely high gas content coals if permeability is very low [44]. Hence, it is important to investigate gas content and permeability mutually. A network of connecting fractures known as cleats as well as natural fractures determine coal permeability [96,138-141]. Depositional environment and tectonics influence permeability distribution. Coal rank, composition, ash content and mineralization are also important controls on permeability [142-144]. Coal permeability is dynamic and can change throughout depletion because of cumulative impact of two competing factors, compaction and matrix shrinkage [145-152]. Magnitude and functional form of permeability change are important in CSG reservoir engineering, reserve estimation and production forecasting. In addition, permeability is an important factor in choosing a suitable completion method [153]. In this section, gas content and permeability of major Australian CSG basins are discussed.

\subsection{Bowen Basin}

Figure 8 shows gas desorption data and coal rank in 28 cored CSG wells in the Bowen Basin. Coals are sub-bituminous to anthracite in rank and there is a weak correlation between gas content and depth. Gas content of low rank coals including sub-bituminous and high volatile bituminous does not exceed $10 \mathrm{~m}^{3} /$ ton (daf) (353 scf/ton) in the Bowen Basin (with a few exceptions). Low volatile bituminous and anthracite are the dominant ranks and coals could be heat affected (see Figure 8). Analysis of gas composition in these core wells reveals that $86 \%$ of gas samples have methane concentration (mole percentage) higher than $95 \%$.

Gas contents of the Bandanna Coals in the Fairview Field are shown separately in Figure 9 (gas desorption data are obtained from 27 observation wells drilled across the field). Although the general trend of increase in gas content with depth is evident, there is variability in gas content within the field. One of the reasons for abnormally low gas contents, reported in some observation wells, could be linked to reservoir depletion. High permeability $(>100 \mathrm{mD})$ and extensive lateral continuity of the Bandanna Coals can result in excellent wellbore connectivity across the field. Hence, gas content measurements in the 
observation wells, drilled recently among existing wells, could be lower than initial gas content values because of depletion by offset wells.

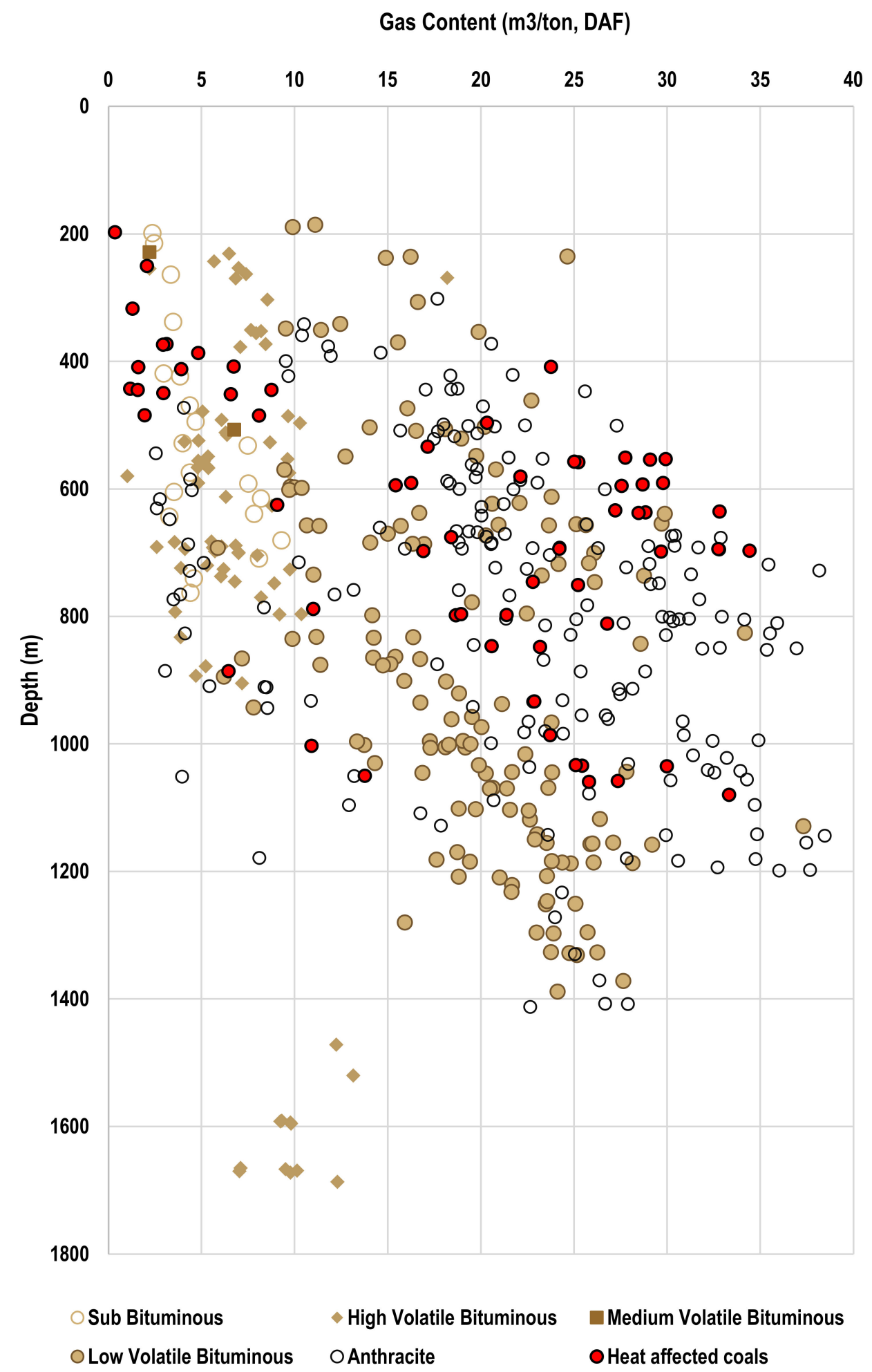

Figure 8. Gas content versus depth measured in 28 CSG core wells in the Bowen Basin. Coal rank is also shown, and heat affected coals are highlighted (data sourced from Queensland Government [154]). 


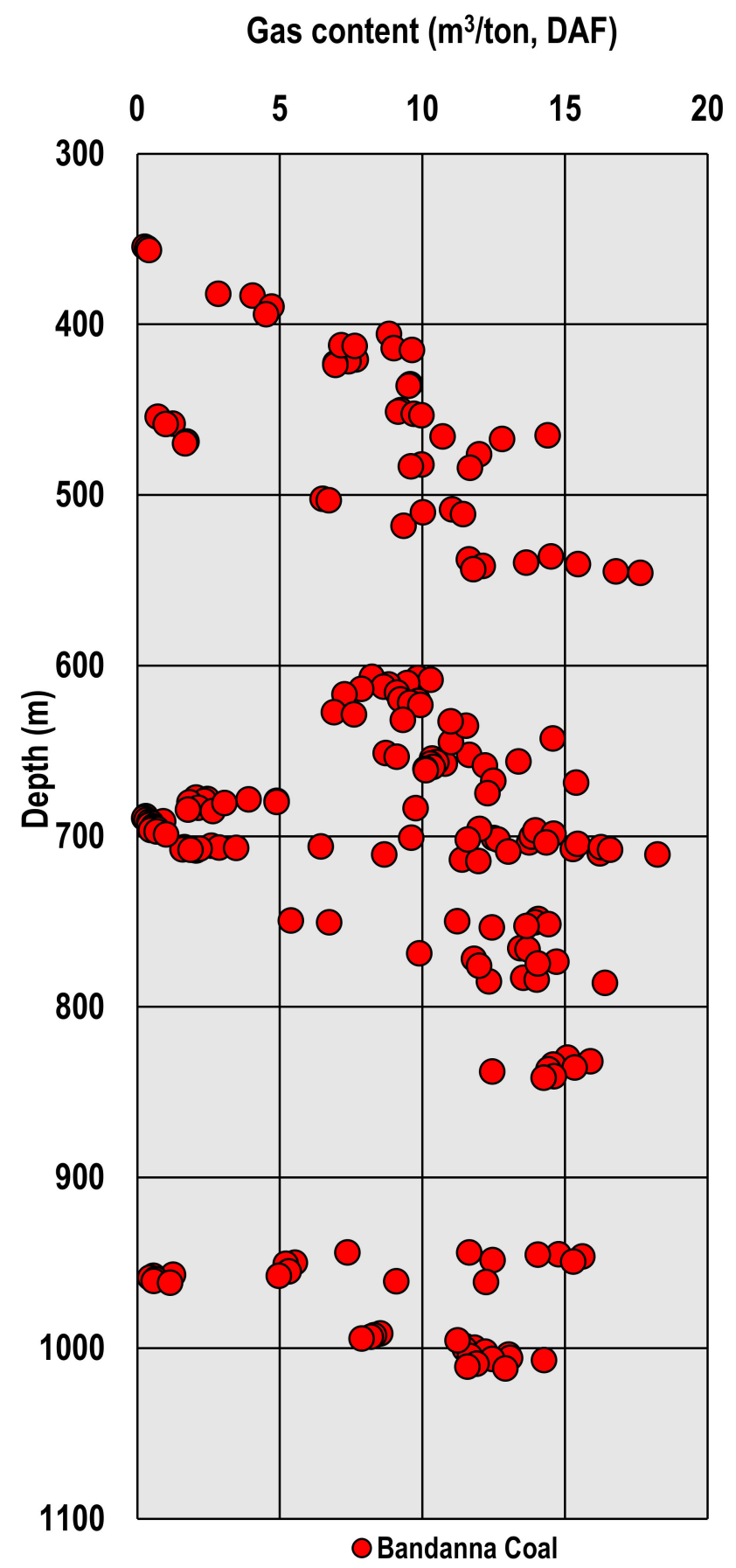

Figure 9. Gas content versus depth for the Bandanna Coals of the Bowen Basin. Variability in gas content is observed across the field (data sourced from Queensland Government [154]).

In the Bowen Basin, coal permeability is low in Moranbah and Moura areas $(<10 \mathrm{mD})$ and hence, in seam drilling technique is vital to promote gas production. On the other hand, permeability in Fairview and Spring Gully is high and cavity completion has been a successful completion technique [153]. The cavity completions in the Fairview are reported to be more successful in more depleted areas and this could be related to permeability enhancement throughout depletion [153]. Several studies in the literature that reported magnitude and/or functional form of permeability change throughout depletion in the Bowen Basin are listed in Table 5. Permeability increase has been reported in the Bandanna Coals and the functional form of increase is exponential [155] similar to Fruitland Coals of the San Juan Basin, the United States, reported by Gierhart, Clarkson [156]. 
Yarmohammadtooski, Salmachi [65] and later Clarkson and Salmachi [160] derived functional form of permeability change (see Figure 10) for a CSG well in the Fairview Field by analysis of production data above and below desorption pressure. Figure 10 shows there is a slight decline in permeability above desorption pressure (during the depressurization phase) because of stress dependency of permeability. It is followed by an increase and then permeability remains unchanged.

Table 5. Some permeability enhancement studies in the Bowen basin (Australia) and the San Juan Basin in the United States.

\begin{tabular}{|c|c|c|}
\hline Author/s & Study Area & Method \\
\hline Mazumder, Scott [157] & Moranbah gas project, Bowen Basin & Time-lapse pressure transient analysis (PTA) \\
\hline Burgoyne and Shrivastava [158] & Scotia Field, Bowen Basin & $\begin{array}{l}\text { Characterization of stress-dependent behaviour } \\
\text { of coal from changes in well productivity }\end{array}$ \\
\hline Belushko, Herwin [159] & Fairview Field, Bowen Basin & Production data analysis \\
\hline $\begin{array}{l}\text { Yarmohammadtooski, Salmachi [65] } \\
\text { Clarkson and Salmachi [160] }\end{array}$ & Fairview Field, Bowen Basin & Production data analysis \\
\hline Salmachi and Barkla [155] & Fairview Field, Bowen Basin & Time-lapse pressure transient analysis \\
\hline $\begin{array}{l}\text { Palmer and Mansoori [149] } \\
\text { Gierhart, Clarkson [156] }\end{array}$ & San Juan Basin, the United States & $\begin{array}{l}\text { Production history matching } \\
\text { Time-lapse PTA of } 28 \text { infill wells }\end{array}$ \\
\hline
\end{tabular}

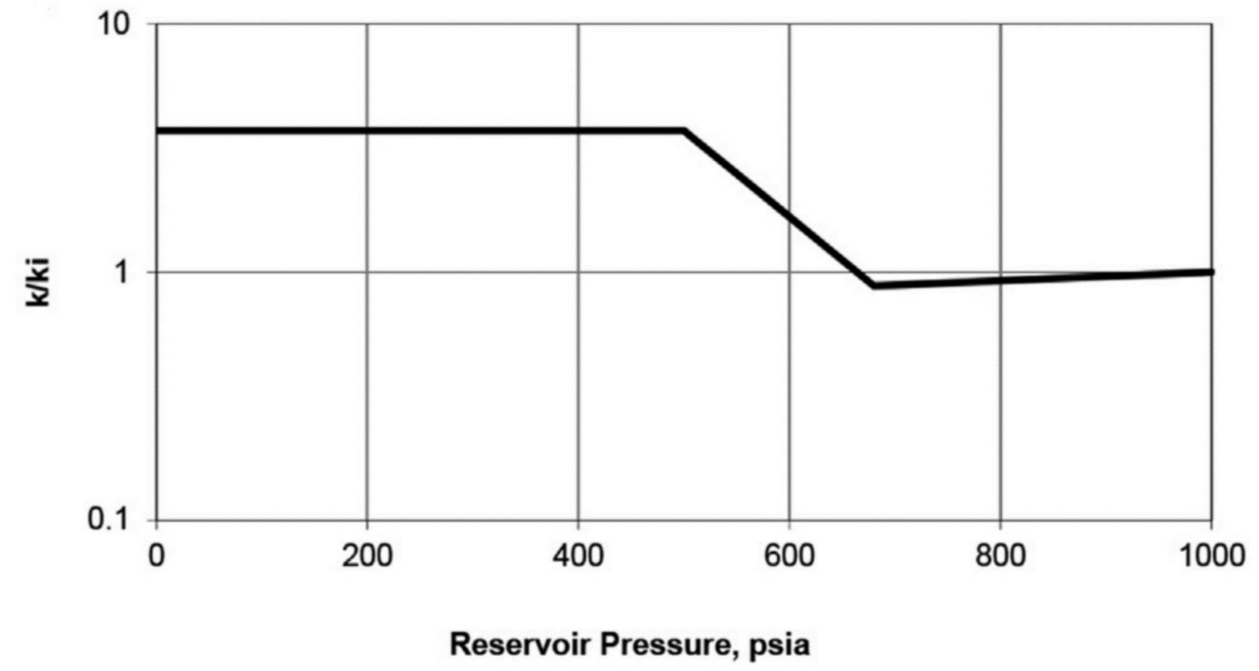

Figure 10. Change in permeability as a function of average reservoir pressure above and below the desorption pressure [160]. There is a slight decrease in permeability above desorption pressure due to stress-dependency of permeability followed by a sharp increase in a short period due to matrix shrinkage effect and then permeability remains unchanged (This figure was originally published in Journal of Natural Gas Science and Engineering Volume 40 Pages 51-60).

Production data analysis works well when there are strong constraints on flowing bottom-hole pressures and reservoir pressures with the latter being more important. When such constraints exist, trends of permeability change with reservoir pressures are very comparable to pressure transient analysis methods. Excellent results (exponential trend) were reported when pressure observation wells, offset to producers, are used to constrain reservoir pressure $[161,162]$. Change in permeability can be investigated by time-lapse pressure transient analysis that includes multiple in situ permeability measurements during depletion. Mazumder, Scott [157] investigated permeability change in 37 horizontal producers (single lateral or chevron geometries) in the Moranbah gas field by performing time-lapse PTA on pressure recovery data during shut-in periods. Although a small number of deviant wells reported, the general trend shows permeability increase by 2 to 50 times as reservoir pressure declines [157].

Salmachi and Barkla [155] replicated pressure build up tests in three CSG wells in the Fairview Field to construct a time-lapse PTA approach to study magnitude and functional 
form of permeability change in the Bandanna Coals. Two of the study wells (Well B and C) followed similar trends in permeability increase and Well A, intersected lower porosity coals, exhibited permeability enhancement by more than one order of magnitude (see Figure 11). Because of limited number of permeability measurements, functional form of change was not determined using the time-lapse PTA. However, rate transient analysis (RTA) of Well B indicates that functional form of permeability enhancement is exponential and a permeability modulus of $-0.00678 \mathrm{psia}^{-1}\left(0.00098335 \mathrm{kPa}^{-1}\right)$ was obtained. The permeability values obtained by the RTA technique are in good agreement with results of pressure transient analysis (See Figure 12).

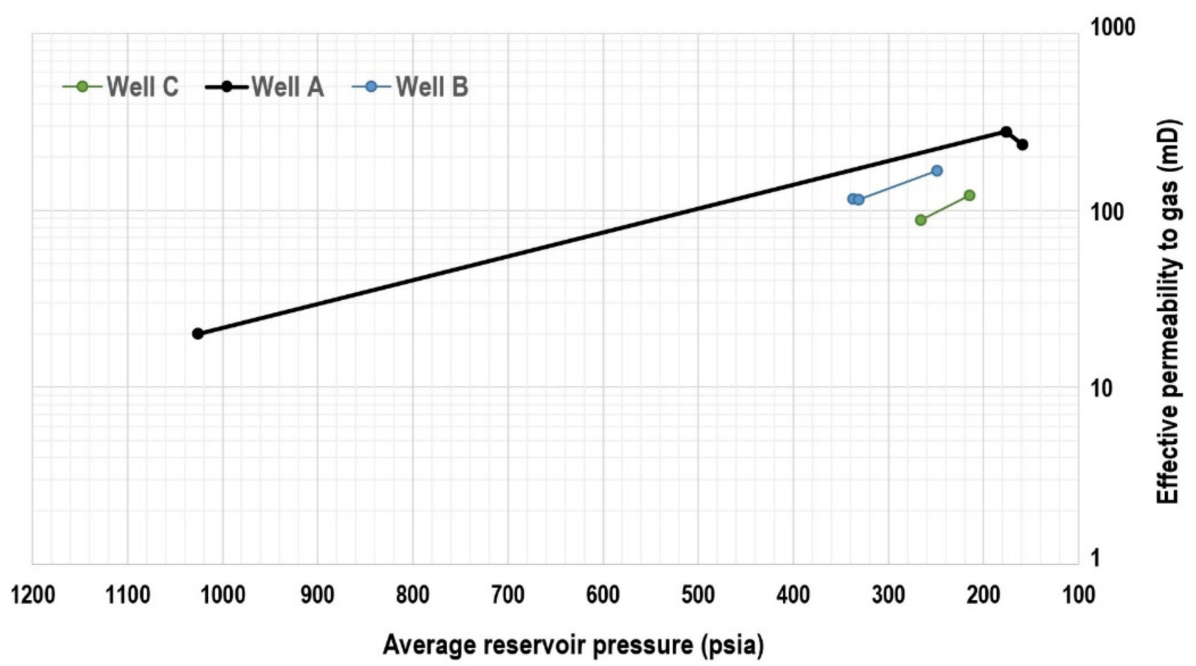

Figure 11. Change of effective permeability as a function of reservoir pressure in the Fairview field, Bowen Basin [155] (This figure was originally published in The APPEA Journal Vol 59 No 1).
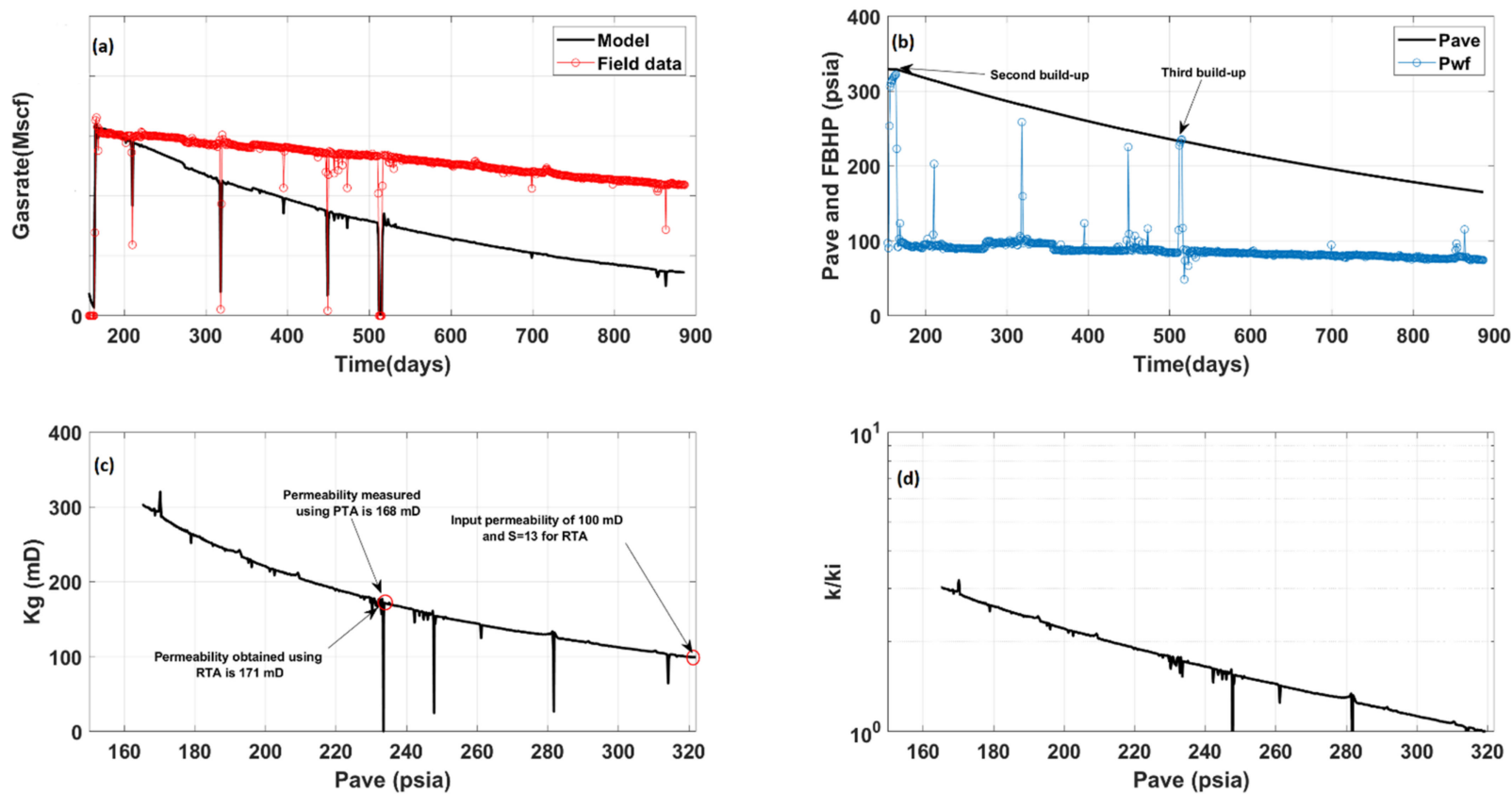

Figure 12. Integration of rate transient analysis and pressure transient analysis to obtain the functional form of permeability change [155] (This figure was originally published in The APPEA Journal Vol 59 No 1). (a) Comparison of field data with tank type model when permeability is constant, (b) bottom-hole flowing pressures and average reservoir pressures, (c) permeability function obtained using RTA, (d) the semi-log plot of permeability ratio as a function of average reservoir pressure is a straight-line (exponential increase). 
Functional form of permeability change versus reservoir pressure depends on many factors including cleat compressibility, coal geomechanical properties and matrix shrinkage $[7,45,146,149,151,155,163,164]$. Coal failure and fine production, when occurs, can result in decrease in permeability and subsequently affect the shape of permeability change curve [165-173]. The impact of coal failure on permeability change in Australian CSG basins is less investigated and requires further research.

\subsection{Sydney-Gunnedah Basins}

Thomson, Thomson [174] divided the Sydney Basin into four distinctive zones to classify gas content and composition. From surface to the depth of $100 \mathrm{~m}$, carbon dioxide (in very low gas content) is the dominant coal seam gas (Zone 1). In Zone 2 (100 $\mathrm{m}$ to $250 \mathrm{~m}$ ) coal seams are rich in methane with biogenic signature. From $250 \mathrm{~m}$ to $600 \mathrm{~m}$ (Zone 3), gas is a mixture of thermogenic and biogenic methane and carbon dioxide with magmatic origin. In Zone 4 (>600 m) thermogenic methane is the dominant gas with some other hydrocarbons (e.g., ethane and propane) [174]. The gas content in the southern Sydney Basin ranges from less than $1 \mathrm{~m}^{3} /$ ton to $23 \mathrm{~m}^{3} /$ ton (daf) with methane and carbon dioxide as dominant components [175].

In an integrated study conducted by Faiz, Stalker [175] information including gas content and composition, coal rank, gas production rate and geological structures were analysed in the Camden area, southern Sydney Basin. Although there is minor variation in coal composition and rank between high and low CSG producers, gases from highly productive wells are dry and have strong biogenic signature in comparison with ethane-rich gasses that are produced from low producing wells. It was concluded that meteoric waters that contain bacteria have reached to high permeable areas, bacteria have metabolized wet gases, and secondary biogenic methane has been generated. Because of this, coals in high permeable areas have higher gas saturation (gas contents closer to sorption capacity) resulting in CSG wells to produce gas more quickly [175].

The target formations in the Camden Gas Project are Bulli and Balgownie coal seams with an average thickness of 4 and $2 \mathrm{~m}$ respectively. Permeability in the Bulli coal seam is in the range of $1-30 \mathrm{mD}$ and gas content is in the range of $6-12 \mathrm{~m}^{3} /$ ton $[113,176]$. In Balgownie coal seam, permeability is less than $1 \mathrm{mD}$ [176].

In the Gunnedah Basin, significant exploration activities including gas content measurements for drilled cores, seismic surveys, drill stem tests and pilot gas production have been executed for the Narrabri Gas Project [113]. Figure 13 shows the relationship between gas content and depth in the Gunnedah Basin. Salmachi, Rajabi [81] showed that, in some of the studied wells across the Gunnedah Basin, magmatic intrusions had a constructive impact on reservoir characteristics of the coal seams by increasing coal rank and gas content. It is also observed that gas composition is primarily methane in coals even at immediate contact with intrusions [81]. These findings are comparable with those reported by Gurba and Ward [136] and Gurba and Weber [77].

Salmachi, Rajabi [81] integrated borehole image logs and DST data to study presence, openness and connectivity of cleats/natural fractures in the Hoskissons Coals in the Gunnedah Basin. The results from 14 wells across the basin indicate that coal permeability can vary from $1091 \mathrm{mD}$ down to almost zero and permeability decreases with depth. It was also observed that natural fractures other than cleats play a significant role in fluid flow. Figure 14 provides a summary of interpretation of cleats and natural fractures in six of the studied wells in the Gunnedah Basin.

High permeable coal intervals have well developed cleat and natural fracture systems (see Glasserton-1 and Dewhurst-19 in Figure 14). Borehole image log interpretation in Kahlua-1 indicates that although coal is poorly cleated, the open fractures within the coal interval result in permeability of $376 \mathrm{mD}$. This highlights the important contribution of natural fractures to coal permeability. 


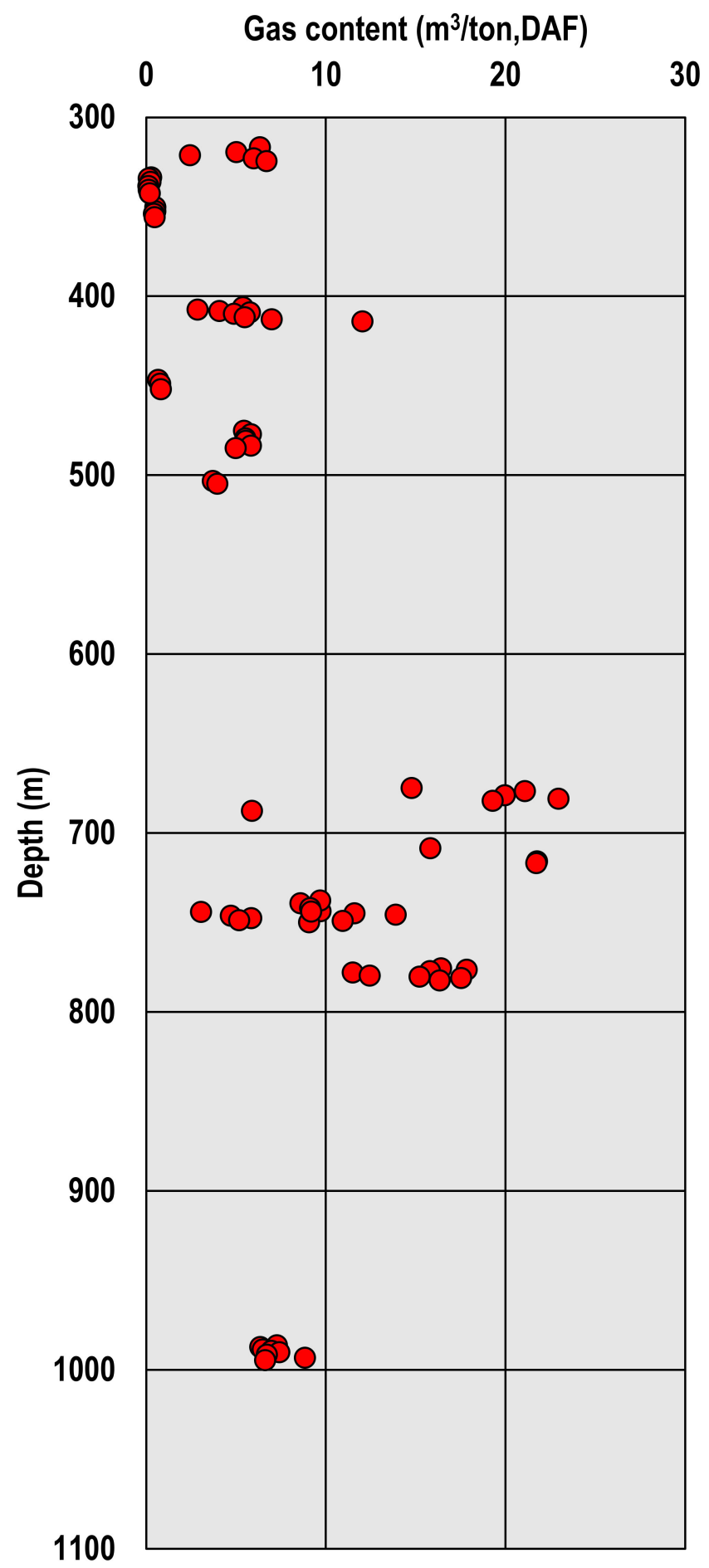

Figure 13. Gas content versus depth for the Hosskisons coal in the Gunnedah Basin. Significant variability in gas content is observed [81] (This figure was originally published in The International Journal of Coal Geology Volume 165 Pages 278-289). 


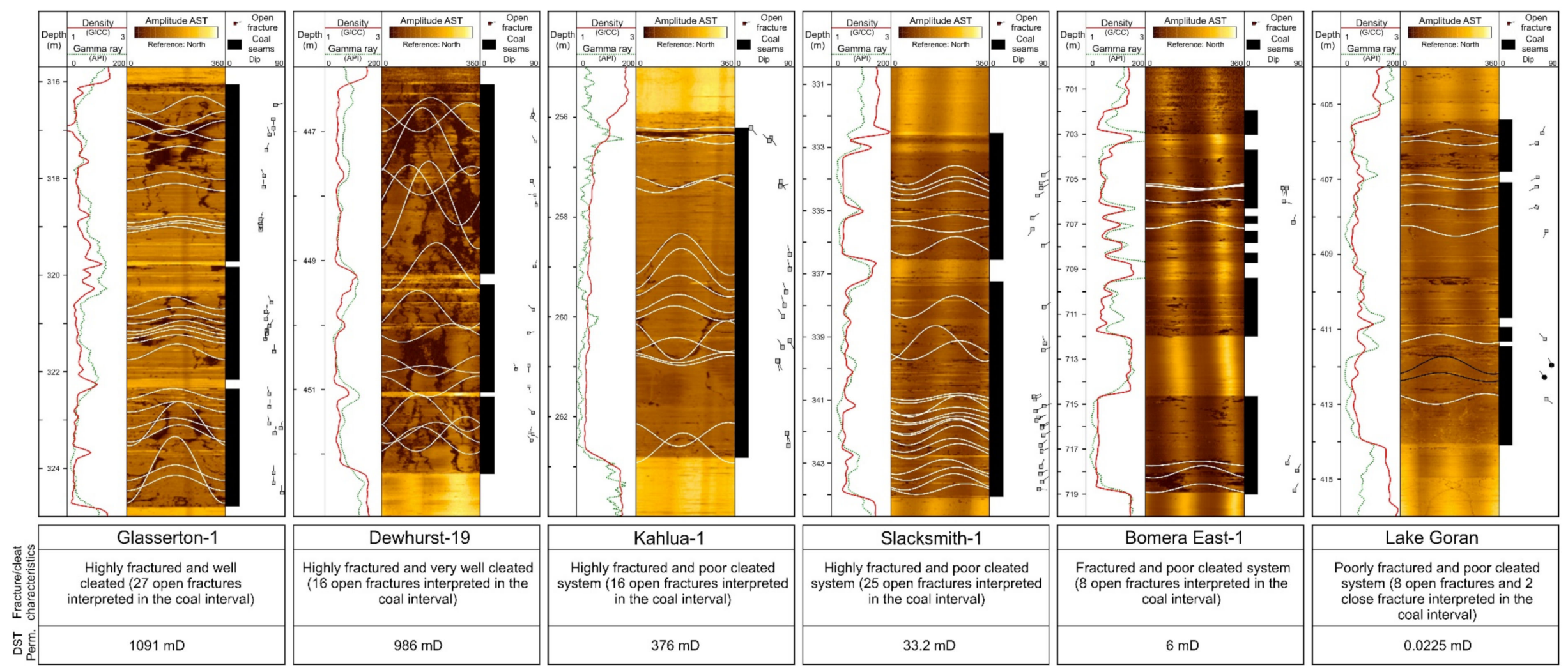

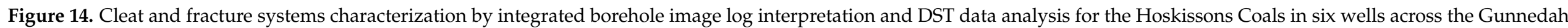
Basin [81] (This figure was originally published in The International Journal of Coal Geology Volume 165 Pages 278-289). 


\subsection{Surat Basin}

Coals in the Surat Basin are less thermally matured $\left(0.42-0.64 \% \mathrm{R}_{\mathrm{o}}\right)$ compared to coals in the Bowen Basin $\left(0.6-3.5 \% R_{\mathrm{o}}\right)$ and hence they generally have lower gas content [24]. Figure 15 shows gas content versus depth in the Surat Basin based on gas desorption data collected from 86 wells [154]. This dataset shows that gas content is lower than $10 \mathrm{~m}^{3} /$ ton (daf) (353 scf/ton), except for a few measurements (see Figure 15). This observation is similar to that of the Bowen Basin where low rank coals show gas contents lower than $10 \mathrm{~m}^{3} /$ ton (daf) (353 scf/ton). The gas content generally increases with depth, but data are scattered. The coals are sub-bituminous and high volatile bituminous in rank. Methane concentration (mole percentage) higher than $95 \%$ were recorded in the majority (96\%) of the gas samples.

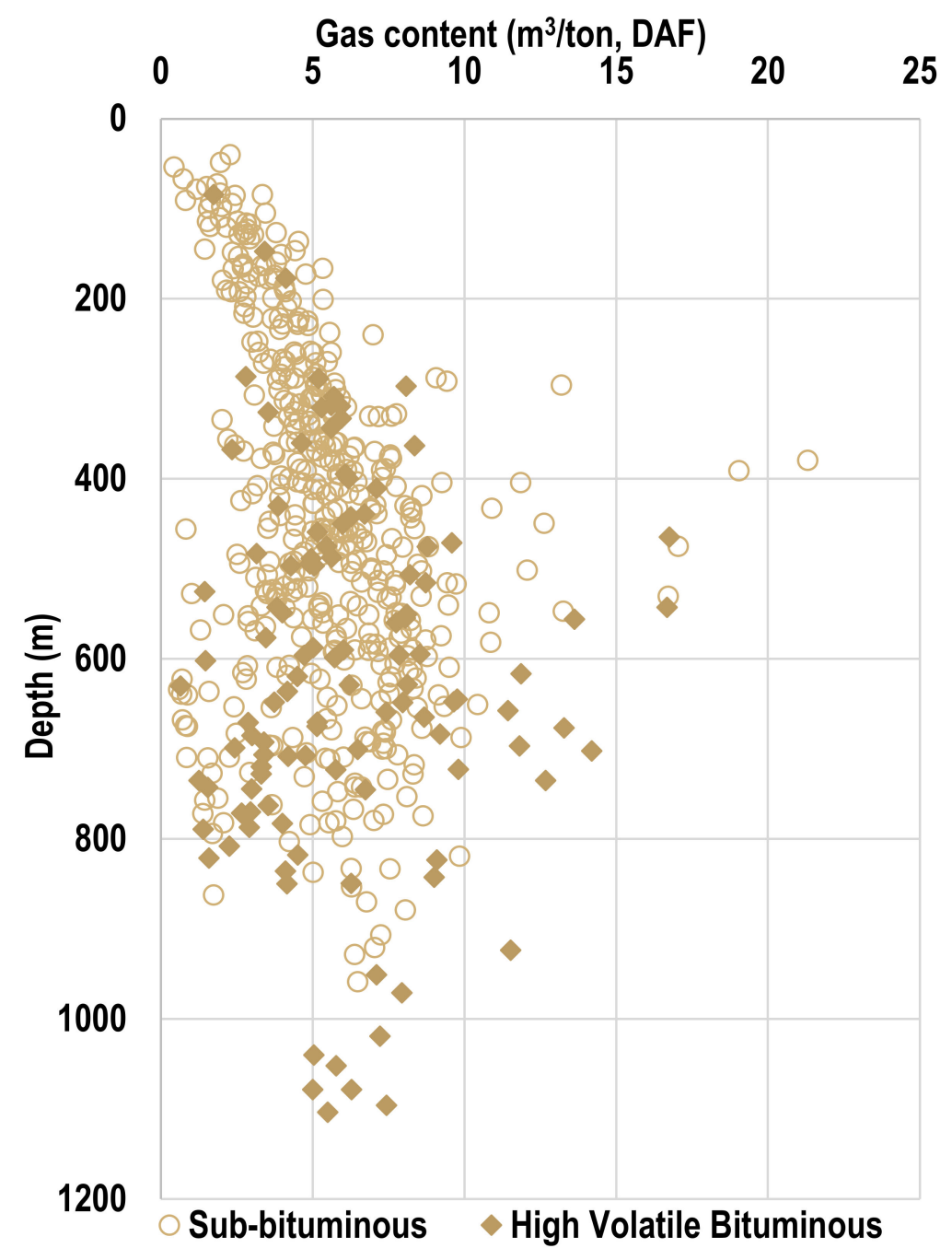

Figure 15. Gas content versus depth in the Surat Basin based on gas desorption data collected from 86 wells [154].

Hamilton, Esterle [101] investigated spatial trends in gas content versus depth in the eastern part of the Surat Basin using core data from 69 CSG wells. Within the studied wells, three trends for gas content were identified; gas content either (1) increase; (2) increase and then decrease; or (3) decrease with depth. The majority of the studied wells fell in the category of 'increase and then decrease' and the inflection point is around the Tangalooma sandstone [101]. This is consistent with the fact that gas content in the Lower Juandah Coal Measures is generally higher than gas content in the Upper Juandah and Taroom Coal Measures [177]. 
Coal seams of the Walloon Coal Measures are thin and does not continue laterally similar to those in the Bowen Basin [24,99]. Although thickness and gas content in the Surat Basin are lower, the key to success in the Surat Basin has been the higher permeability. Permeability of the Walloon Coal Measures ranges from 5-5000 mD [178]. Structural deformation is an important mechanism responsible for enhancement of coal permeability in the Surat Basin [177]. Undulla nose and Kogan anticline are two important structural features that have higher permeability and host important CSG fields in the Surat Basin. Coal composition is another factor that controls fracture density within coal seams and, hence, permeability $[94,179]$. Core analysis in the Surat Basin indicates that cleat and fracture networks are largely related to bright vitrinite-rich coal layers. Lower Juandah Coal Measures that contain higher vitrinite compared to Upper Juandah Coal Measures and Taroom Coal Measures, have higher permeability [177].

Figure 16 shows in situ permeability versus depth for the Taroom Coal Measures and Upper and Lower Juandah Coal Measures measured by pressure transient analysis method. The general trend shows decline with depth however, there is significant variability in permeability. For example, in the Lower Juandah Coal Measures, at the depth of $\sim 310 \mathrm{~m}$, permeability values of $0.05 \mathrm{mD}$ and $860 \mathrm{mD}$ have been reported in two different wells (see Figure 16). The major reasons behind such differences include geological structures, coal maturity, permeability measurement methods, stress regime, fracture/cleat density, localized shear zones and cleat mineralization [81,117,180-183]. In situ permeability measurement in a CSG well provides an average value for permeability for all intersected coal seams in the tested interval. Since up to 45 individual thin coal seams can be intersected in the Walloon Subgroup [177], it is difficult to determine vertical heterogeneity of the system.

The vertical heterogeneity and lateral discontinuity of the coal seams in the Surat Basin pose a great challenge on production history matching to obtain reservoir properties [184]. Mazumder, Jiang [178] performed production history matching on 14 wells in the Surat Basin and reported permeability values in the range of $65-310 \mathrm{mD}$ for the wells completed in the Taroom Coals, $90-275 \mathrm{mD}$ for the wells completed in the Juandah Coals and $75-320 \mathrm{mD}$ for the wells completed commingled across both Taroom and Juandah coals. The commingled production in the Surat Basin can result in coal seams with lower reservoir pressures to contribute to gas production later when high-pressure seams are depleted. This may result in increase in gas production rate after a period of decline [178]. 


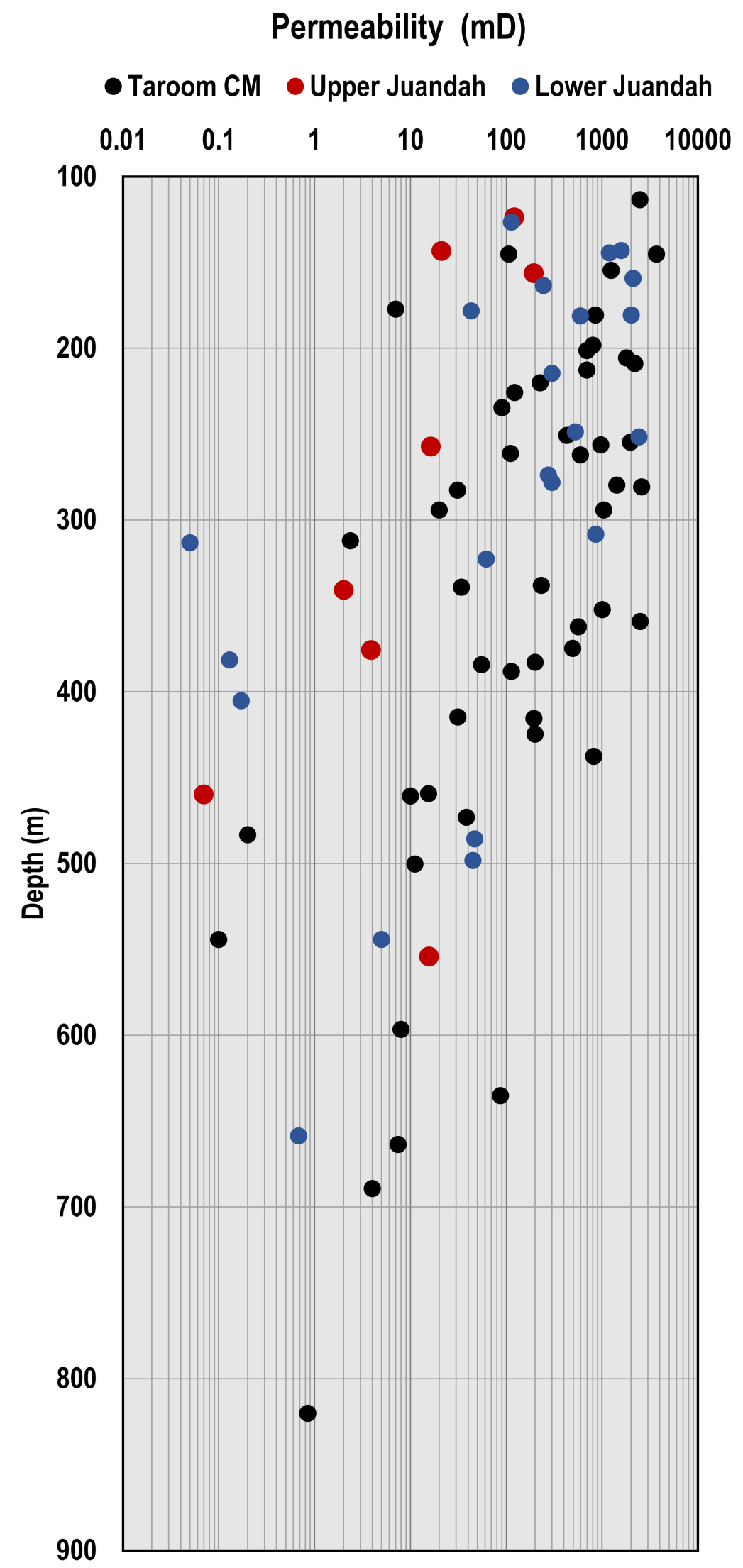

Figure 16. Permeability versus depth in the Surat Basin, QLD [117]. 


\subsection{Cooper Basin}

Thick and laterally extensive Permian deep coal seams (>2 km) in the Cooper Basin, South Australia, are considered huge, underdeveloped resources. Patchawarra Formation accommodates a large bulk of deep coal seams and is the primary target for development. Figure 17 shows the isolith map of the Patchawarra Coal showing net coal thickness across the Cooper Basin [7]. The thickness of an individual coal seam in the Patchawarra formation can reach to $45 \mathrm{~m}(148 \mathrm{ft}$.$) [5,29].$

A number of reported gas contents for the upper Patchawarra Formation, including those tested in Dorodillo-2, are very high. This is likely an overestimation because they were conventionally cored and core retrieval process results in extended lost gas time. Hence, lost gas volume estimates are higher than actual resulting in overestimation of gas contents. Diamond and Schatzel [133] suggested that lost gas volume can be reasonably estimated when lost gas time is less than one hour. In Dorodillo-2, lost gas time was $6 \mathrm{~h}$ and $19 \mathrm{~min}$ [185] that is much longer than the limit of $1 \mathrm{~h}$ suggested by Diamond and Schatzel [133]. Gas contents of core samples in deep coal wells that are conventionally cored should be treated very carefully because extended lost gas time increases the error in estimation method. More recent mixed isotherm analysis of three core samples of varying coal rank, suggests the total measured gas is likely within the range of $11.04-19.26 \mathrm{~m}^{3} /$ ton (daf) (390-680 scf/ton) for Patchawarra deep coals (Bindah-3; Kirralee-2; and Bobs Well-2). Total gas content in deep coal seams can be measured more accurately using pressure coring techniques.
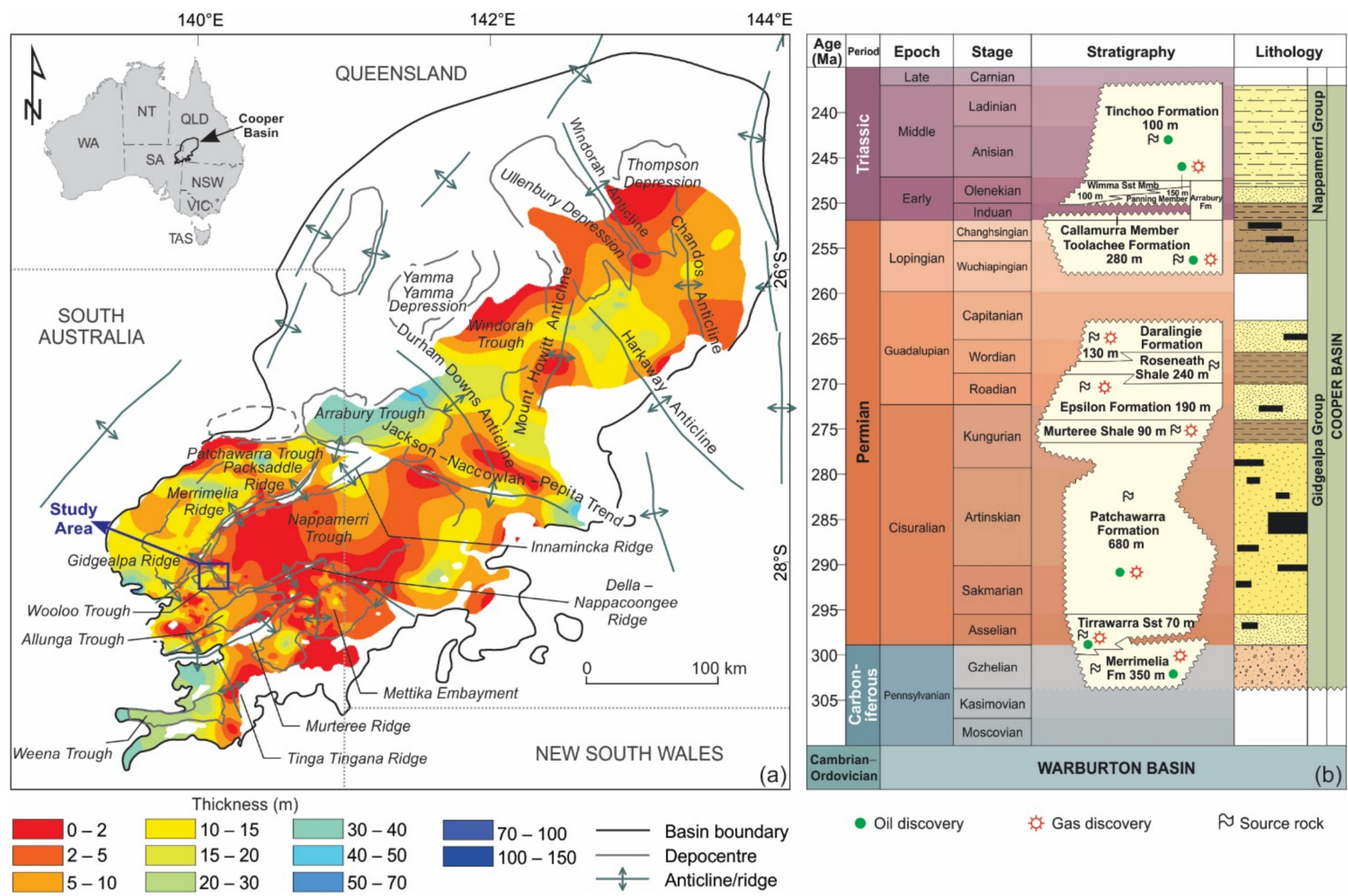

Figure 17. (a) Isolith map of the Patchawarra Coal showing net coal thickness in the Patchawarra Formation across the Cooper Basin, (b) the stratigraphic column of the Cooper Basin [186-188] (This figure was originally published in The AAPG Bulletin Vol 103 Issue 1 Pages 91-107). 
In the southern part of the Cooper Basin, Patchawarra coal seams are thick, shallower, and higher in permeability but lower in gas content. Vu upper coal seam interested in Le Chiffre- 1 and Klebb- 1 is 35 m thick. Figure 18 shows gas contents in Le Chiffre- 1 that has $461 \mathrm{~m}$ of cores that were taken from $1464 \mathrm{~m}$ to $2044 \mathrm{~m}$ using the wireline retrievable coring [189]. The lost gas time for samples is generally less than $1 \mathrm{~h}$ and gas contents range from $1.36-6.81 \mathrm{~m}^{3} /$ ton (daf). The side-wall pressure cores obtained later from Klebb5 (located in proximity to Le Chiffre- 1 and Klebb-1) indicated that average gas content (methane) in the Klebb area is $5.5 \mathrm{~m}^{3} /$ ton (194 scf/ton) [190]. Vm3, Vu upper and lower coal seams in the Klebb pilot have low gas saturation. Hence, a significant depressurization phase is needed to achieve commercial production rates. This is a barrier for development of deep coal seams in the southern part of the Cooper Basin.

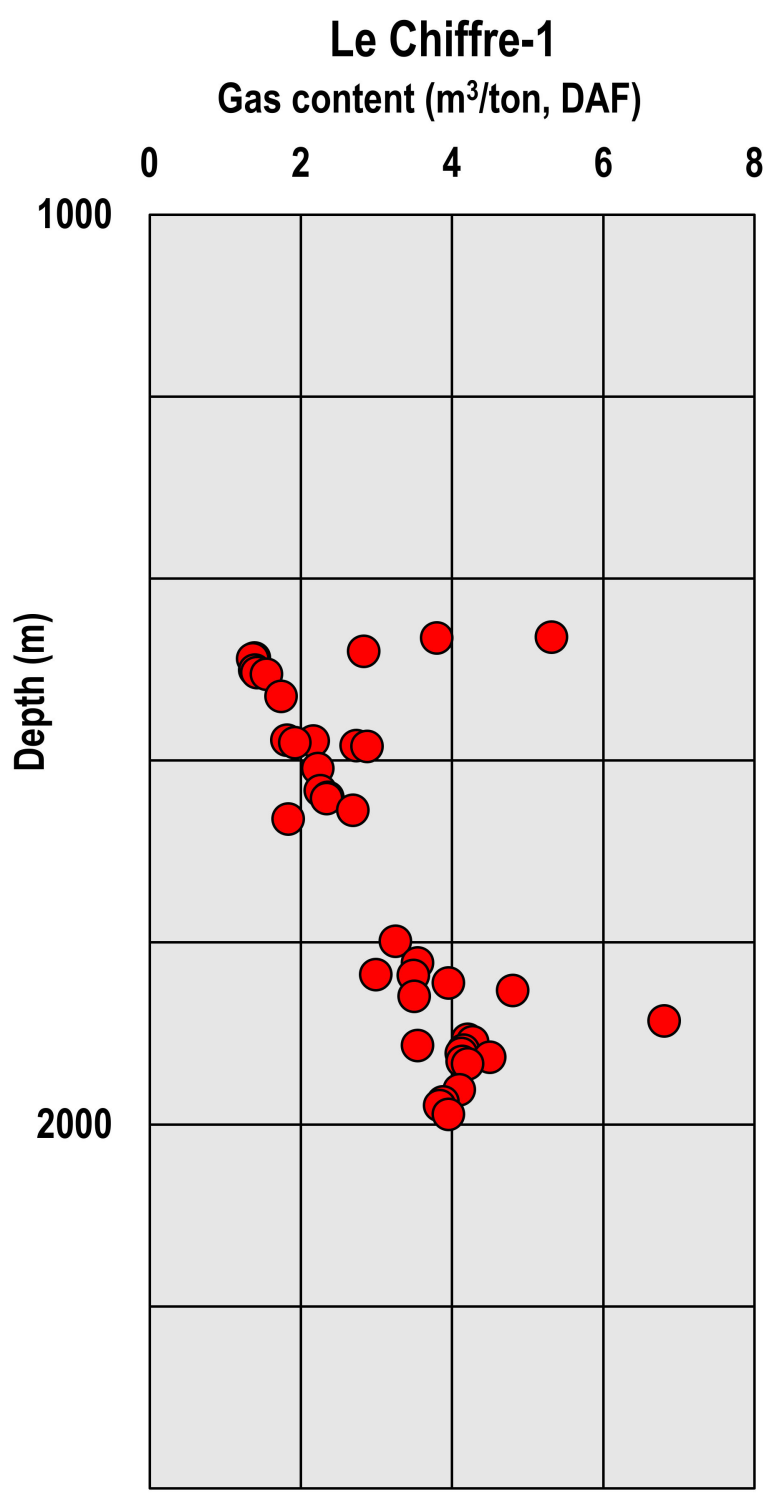

Figure 18. Gas content of deep coal seams in Le Chiffre-1 drilled in the Weena Trough, southern part of the Cooper Basin [189].

Permeability of deep coal seams is in the range of micro- to nano-darcy [29] hence, hydraulic fracturing is necessary to achieve economical gas rate. The Cooper Basin deep coal "add-on" frac campaign involves placing hydraulic fractures in thick deep coal seams in gas development wells. This program is considered an overall economic success with variable productivity [3]. These development wells mostly target tight sandstone reservoirs 
in the Cooper Basin and the excess gas from deep coal seams adds further contribution to overall production. Average gas production from single-stage fracture stimulated coals is $0.2 \mathrm{mmscf} /$ day and that can reach to $1 \mathrm{mmscf} /$ day in some wells [3].

Dunlop, Salmachi [5], utilized a comprehensive data set from a hydraulically fractured well, completed in deep Patchawarra coal seams of the Cooper Basin, and demonstrated that hydraulic fracture conductivity can improve throughout the life of the well. The increase in fracture conductivity could be attributed to the cumulative impact of a number of factors including coal matrix shrinkage, recovery of residual hydraulic fracture fluid and erosion of the fracture faces due to proppant embedment. An earlier study on this wellbore by Salmachi, Dunlop [7] concluded that depletion is limited to the stimulated reservoir area adjacent to hydraulic fractures. The excessive gas desorption from near wellbore area can potentially promote matrix shrinkage effect. The matrix shrinkage can enlarge hydraulic fracture aperture and improve fracture conductivity. Further research is needed to understand the mechanisms contributing to increase in hydraulic fracture conductivity in deep coal wells.

\section{Summary}

In late 2018, Australia became the largest exporter of LNG in the world and $29 \%$ of the country's LNG nameplate capacity is in three facilities in east coast that are primarily fed by coal seam gas. The current estimate for the Australia's CSG reserves is 43 Tcf from which $92.5 \%$ lie within Surat and Bowen basins of Queensland. The 13\% Gas Scheme and the idea of converting CSG to LNG for exports were two critical decisions that boosted commercial CSG production in Queensland. In the Bowen Basin, the three stratigraphic units that are major targets for CSG production include Moranbah Coal Measures/German Creek Formation, the Baralaba Coal Measures and the Bandanna Formation. In the Surat Basin, the major producing CSG interval is the Jurassic Walloon Coal Measures. Coals in the Surat Basin are low in rank and gas content is generally lower than $10 \mathrm{~m}^{3} /$ ton (daf). The key to success in CSG development in the Surat Basin is high permeability that can range from 5-5000 mD. In the Bowen Basin, coals are higher in rank (low volatile bituminous and anthracite) and gas contents are generally higher than those in the Surat Basin are. The significant variability in gas content and permeability in Australian CSG basins are attributed to geological structures, coal rank, stress regime, measurement methods, magmatism and sealing capacity of overlying formations. Field studies indicate that coal permeability in Australian fields can vary during depletion and the functional form of permeability change with reservoir pressure is exponential, consistent with producing CSG fields in North America.

Detailed analyses of high-resolution borehole image logs in CSG wells indicate that there are major perturbations in $\mathrm{S}_{\mathrm{Hmax}}$ orientation, both spatially and with depth in Australian CSG basins. The regional orientation of $\mathrm{S}_{\mathrm{Hmax}}$ in the northern part of the Bowen Basin is NNE-SSW. In the Clarence-Moreton, Surat and southern part of the Bowen basins, the regional $\mathrm{S}_{\mathrm{Hmax}}$ orientation is NE-SW to ENE-WSW. The Cooper Basin in central Australia has a significant E-W $\mathrm{S}_{\mathrm{Hmax}}$ orientation. In the Gunnedah Basin, the geological structures, including faults, fracture and magmatism have strongly perturbed stresses in the region. Analysis of micro-seismic and tilt-meter results indicate that in areas with high differential stresses (in reverse stress regime) planar hydraulic fractures propagate. In areas with low differential stresses, both stresses and pre-exiting natural fractures control hydraulic fracture propagation resulting in more complex fracture patterns.

In 2007, for the first time, Patchawarra coal seams were hydraulically fractured in Moomba 77 and a gas flowrate of $\sim 0.1 \mathrm{mmscf} /$ day was reported. Extended lost gas times in deep coal wells that are cored conventionally pose a challenge to accurately measure gas contents. Pressure core can provide a more accurate estimation of gas content in deep coal seams than conventional desorption canisters do. Since 2013, gas production exclusively from deep coal seams has been tested as a single add-on fracture stimulation in vertical well completions across the Cooper Basin. 
Author Contributions: Formal analysis and investigation, A.S., M.R., S.M., C.W., P.M., B.C. and C.C.; writing-review and editing, A.S., M.R., S.M., C.W., P.M., B.C. and C.C.; visualization, M.R. and A.S. All authors have read and agreed to the published version of the manuscript.

Funding: This research received no external funding.

Institutional Review Board Statement: Not applicable.

Informed Consent Statement: Not applicable.

Data Availability Statement: Majority of data presented in this study are openly available in government websites. Please refer to the reference section to find the address for each dataset. Restrictions may apply to the availability of some data presented in this study.

Acknowledgments: We like to acknowledge Tim A. Moore, Managing Director, Cipher Consulting Pty. Ltd. for his comprehensive and careful review of this review paper. We like to acknowledge Suyang Zhu from Southwest Petroleum University, China, for providing insights and information on deep coal seams in China. We also like to acknowledge the anonymous reviewers who spent significant time and effort to improve the quality of this paper. Mojtaba Rajabi's contribution was funded through the ARC Discovery Early Career Researcher Award (DE200101361).

Conflicts of Interest: The authors declare no conflict of interest.

\section{Table of Conversions}

$\begin{array}{ll}1 \mathrm{~m}^{3} & 35.3 \mathrm{ft}^{3} \\ 1 \mathrm{~m} & 3.28 \mathrm{ft} \\ 1 \mathrm{~km} & 1000 \mathrm{~m} \\ 1 \mathrm{psi} & 6.89 \mathrm{kPa} \\ 1 \mathrm{psi} & 0.00689 \mathrm{MPa}\end{array}$

\section{Nomenclature}

$\begin{array}{ll}B c f & \text { Billion cubic feet } \\ d a f & \text { Dry ash free } \\ k & \text { Permeability } \\ k_{g} & \text { Effective permeability to gas } \\ k_{i} & \text { Initial permeability } \\ k_{r} & \text { Relative permeability } \\ m m s c f / \text { day } & \text { Million standard cubic feet per day } \\ m s c f / \text { day } & \text { Thousand standard cubic feet per day } \\ P_{\text {ave }} & \text { Average reservoir pressure } \\ P_{w f} & \text { Flowing bottom-hole pressure } \\ S_{h m a x} & \text { Maximum horizontal Stress } \\ \text { Tcf } & \text { Trillion cubic feet }\end{array}$

\section{References}

1. Australian Government. Resources and Energy Quarterly. June 2018. Available online: https://publications.industry.gov.au/ publications/resourcesandenergyquarterlyjune2018/documents/Resources-and-Energy-Quarterly-June-2018-Gas.pdf (accessed on 1 March 2020).

2. Branajaya, R.; Archer, P.; Farley, A. Pushing the boundaries-deployment of innovative drilling, completion and production technology to advance a deep coal seam play. APPEA J. 2019, 59, 770-775. [CrossRef]

3. Camac, B.; Benson, J.; Chan, V.; Goedecke, A. Cooper Basin Deep Coal-the New Unconventional Paradigm: Deepest Producing Coals in Australia. ASEG Extended Abstr. 2018, 2018, 1-7. [CrossRef]

4. Cooper, G.; Lockhart, D.; Walsh, A. The Permian Deep Coal Play, Cooper Basin, Australia. Unlocking the Next Gas Giant. In Proceedings of the SPE Asia Pacific Oil and Gas Conference and Exhibition, Brisbane, Australia, 23-25 October 2018; Society of Petroleum Engineers: Brisbane, Australia, 2018; p. 19.

5. Dunlop, C.E.; Salmachi, A.; McCabe, P.J. Investigation of increasing hydraulic fracture conductivity within producing ultra-deep coal seams using time-lapse rate transient analysis: A long-term pilot experiment in the Cooper Basin, Australia. Int. J. Coal Geol. 2020, 220, 103363. [CrossRef] 
6. Fraser, S.A.; Johnson, R.L., Jr. Impact of Laboratory Testing Variability in Fracture Conductivity for Stimulation Effectiveness in Permian Deep Coal Source Rocks, Cooper Basin, South Australia. In Proceedings of the SPE Asia Pacific Oil and Gas Conference and Exhibition, Brisbane, Australia, 23-25 October 2018; Society of Petroleum Engineers: Brisbane, Australia, 2018 ; p. 19.

7. Salmachi, A.; Dunlop, E.; Rajabi, M.; Yarmohammadtooski, Z.; Begg, S. Investigation of permeability change in ultradeep coal seams using time-lapse pressure transient analysis: A pilot project in the Cooper Basin, Australia. AAPG Bull. 2019, 103, 91-107. [CrossRef]

8. Moore, T. Coalbed methane: A review. Int. J. Coal Geol. 2012, 101, 36-81. [CrossRef]

9. Zhang, J.; Feng, Q.; Zhang, X.; Wen, S.; Zhai, Y. Relative permeability of coal: A review. Transp. Porous Media 2015, 106, 563-594. [CrossRef]

10. Pan, Z.; Connell, L.D. Modelling permeability for coal reservoirs: A review of analytical models and testing data. Int. J. Coal Geol. 2012, 92, 1-44. [CrossRef]

11. Clarkson, C. Production data analysis of unconventional gas wells: Review of theory and best practices. Int. J. Coal Geol. 2013, $109,101-146$.

12. Miyazaki, S. Coal seam gas exploration, development and resources in Australia: A national perspective. APPEA J. 2005, 45, 131-142. [CrossRef]

13. Towler, B.; Firouzi, M.; Underschultz, J.; Rifkin, W.; Garnett, A.; Schultz, H.; Esterle, J.; Tyson, S.; Witt, K. An overview of the coal seam gas developments in Queensland. J. Nat. Gas Sci. Eng. 2016, 31, 249-271. [CrossRef]

14. Rajabi, M.; Tingay, M.; Heidbach, O.; Hillis, R.; Reynolds, S. The present-day stress field of Australia. Earth Sci. Rev. 2017, 168, 165-189.

15. Queensland Government. Petroleum and Gas Production Statistics. 2019. Available online: https://www.data.qld.gov. $\mathrm{au} /$ dataset/petroleum-gas-production-and-reserve-statistics/resource/9746212a-e0c6-484d-95ad-b2be1c46027d (accessed on 15 October 2020).

16. Energy Information Administration. US Coalbed Methane Production 2020 cited 2020. Available online: https://www.eia.gov/ dnav/ng/ng_prod_coalbed_s1_a.htm (accessed on 15 October 2020).

17. International Energy Agency. Key world Energy Statistics, Coal Production. p. 17. 2017. Available online: https://www.iea.org/ publications / freepublications/publication/KeyWorld2017.pdf (accessed on 16 February 2020).

18. Geoscience Australia. Australia Energy Resource Assessment. 2019. Available online: https://aera.ga.gov.au/ (accessed on 12 March 2020).

19. Flores, R.M. Coalbed methane: From hazard to resource. Int. J. Coal Geol. 1998, 35, 3-26. [CrossRef]

20. McLennan, J.D. A Guide to Determining Coalbed Gas Content; Schafer, P.S., Ed.; Gas Research Institute: Chicago, IL, USA, 1995.

21. Diamond, W.P. Evaluation of the methane gas content of coalbeds: Part of a complete coal exploration program for health and safety and resource evaluation. In Proceedings of the 2nd International Coal Exploration Symposium, Denver, CO, USA, October 1978.

22. Riley, J. The rise and rise of Coal Seam Gas in the Bowen Basin. APPEA J. 2004, 44, 647-652. [CrossRef]

23. Cullicott, C.; Dunmire, C.; Brown, J.; Calwell, C. Coalbed Methane in the San Juan Basin of Colorado and New Mexico, in Coalbed Methane Development in the Intermountain West. University of Colorado Boulder, Natural Resources Law Center: Boulder, CO, USA, 2002.

24. Queensland Government. Queensland's Petroleum and Coal Seam Gas. 2017; p. 8. Available online: http:/ /www.australiaminerals. gov.au/_data/assets/pdf_file/0003/47622/Queenslands-petroleum-and-coal-seam-gas-2017.pdf (accessed on 20 April 2020).

25. Queensland Government. Queensland Gas Scheme, Business Queensland. 2014. Available online: https://web.archive.org/ web / 20110422191442/http:/ / www.dme.qld.gov.au/Energy/gasscheme.cfm (accessed on 20 January 2020).

26. Energy Quest, Queensland LNG Projects Facing Supply Crunch. 2019. Available online: https://www.lngworldnews.com/ energyquest-queensland-lng-projects-facing-supply-crunc/ (accessed on 11 June 2020).

27. Queensland Government. Petroleum and Gas Production and Reserve Statistics. 2019. Available online: https://www.data.qld. gov.au/dataset/ petroleum-gas-production-and-reserve-statistics (accessed on 5 March 2020).

28. Santos. Narrabri Gas Project. 2020. Available online: https://narrabrigasproject.com.au/2020/07/ceo-ipc-speech-narrabri-gasproject/ (accessed on 20 January 2021).

29. Dunlop, E.C.; Warner, D.S.; Warner, P.E.; Coleshill, L.R. Ultra-deep Permian coal gas reservoirs of the Cooper Basin: Insights from new studies. APPEA J. 2017, 57, 218-262.

30. Menpes, S.; Hill, T. Emerging continuous gas plays in the Cooper Basin, South Australia. APPEA J. 2012, $52,671$.

31. Olson, T.M. White River Dome Field: Gas Production from Deep Coals and Sandstonesof the Cretaceous Williams Fork Formation, Piceance Basin Guidebook; AAPG: Tulsa, OK, USA, 2003.

32. Camac, B.; Santos Ltd., 60 Flinders Street, Adelaide, SA 5000, Australia. Personal communication, 2019.

33. Strike Energy. The Southern Cooper Basin Gas Project. 2017. Available online: https://strikeenergy.com.au/cooper-basin/ (accessed on 4 March 2020).

34. Strike Energy. Cooper Basin Update. p. 1. 2020. Available online: https://strikeenergy.com.au/asx-announcements/ (accessed on 15 January 2021).

35. Thomas, L. Coal Geology; Wiley Online Library: New York, NY, USA, 2013.

36. Ward, C.; Harrington, H.; Mallett, C.; Beeston, J. Geology of Australian Coal Basins; Geological Society of Australia, Coal Geology Group: Hornsby, Australia, 1995. 
37. Burra, A.; Esterle, J.S.; Golding, S.D. Horizontal stress anisotropy and effective stress as regulator of coal seam gas zonation in the Sydney Basin, Australia. Int. J. Coal Geol. 2014, 132, 103-116. [CrossRef]

38. Bustin, R.M. Importance of Fabric and Composition on the Stress Sensitivity of Permeability in Some Coals, Northern Sydney Basin, Australia: Relevance to Coalbed Methane Exploitation1. AAPG Bull. 1997, 81, 1894-1908.

39. Bustin, M.R.; Clarkson, C.R. Geological controls on coalbed methane reservoir capacity and gas content. Int. J. Coal Geol. 1998, 38, $3-26$.

40. Draper, J.; Boreham, C. Geological controls on exploitable coal seam gas distribution in Queensland. Aust. Pet. Prod. Explor. Assoc. 2006, 46, 343-366. [CrossRef]

41. Laxminarayana, C.; Crosdale, P.J. Role of coal type and rank on methane sorption characteristics of Bowen Basin, Australia coals. Int. J. Coal Geol. 1999, 40, 309-325.

42. Pashin, J.C. Stratigraphy and structure of coalbed methane reservoirs in the United States: An overview. Int. J. Coal Geol. 1998, 35, 209-240. [CrossRef]

43. Pashin, J.C. Coal as a petroleum source rock and reservoir rock. In Applied Coal Petrology; Elsevier: Amsterdam, The Netherlands, 2008; pp. 227-262.

44. Scott, A.R. Hydrogeologic factors affecting gas content distribution in coal beds. Int. J. Coal Geol. 2002, 50, 363-387. [CrossRef]

45. Seidle, J. Fundamentals of Coalbed Methane Reservoir Engineering; PennWell Books: Tulsa, OK, USA, 2011.

46. Boreham, C.; Golding, S.; Glikson, M. Factors controlling the origin of gas in Australian Bowen Basin coals. Org. Geochem. 1998, $29,347-362$.

47. Golding, S.D.; Baublys, K.A.; Glikson, M.; Uysal, I.T.; Boreham, C.J. Source and Timing of Coal Seam Gas Generation in Bowen Basin Coals. In Coalbed Methane: Scientific, Environmental and Economic Evaluation; Mastalerz, M., Glikson, M., Golding, S.D., Eds.; Springer Netherlands: Dordrecht, The Netherlands, 1999; pp. 257-269.

48. Hamilton, S.K.; Golding, S.D.; Esterle, J.S.; Baublys, K.A.; Ruyobya, B.B. Controls on Gas Domains and Production Behaviour in A High-Rank CSG Reservoir: Insights from Molecular and Isotopic Chemistry of Co-Produced Waters and Gases from the Bowen Basin, Australia. Geosciences 2020, 10, 74.

49. Green, P.; Hoffmann, K.; Brain, T.; Gray, A. The Surat and Bowen basins, south-east Queensland. In Queensland Minerals and Energy Review Series; Queensland Department of Mines and Energy: Brisbane, Australia, 1997.

50. Babaahmadi, A.; Sliwa, R.; Esterle, J.; Rosenbaum, G. The development of a Triassic fold-thrust belt in a synclinal depositional system, Bowen Basin (eastern Australia). Tectonics 2017, 36, 51-77.

51. Brakel, A.T.; Totterdell, J.M.; Wells, A.T.; Nicoll, M.G. Sequence stratigraphy and fill history of the Bowen Basin, Queensland. Aust. J. Earth Sci. 2009, 56, 401-432. [CrossRef]

52. Sliwa, R.; Esterle, J. Rangal Supermodel 2015. APPEA J. 2016, 56, 598.

53. Jell, P. Geology of Queensland; Queensland Geological Survey of Queensland: Brisbane, Australia, 2013.

54. Mallett, C.; Pattison, C.; McLennan, T.; Balfe, P.; Sullivan, D. Bowen Basin. Special Publication of the Geological Society of Australia; Geological Society of Australia, Coal Geology Group: Hornsby, Australia, 1995; Volume 1, pp. 299-339.

55. Korsch, R.J.; Totterdell, J.M.; Cathro, D.L.; Nicoll, M.G. Early Permian East Australian Rift System. Aust. J. Earth Sci. 2009, 56, 381-400. [CrossRef]

56. Boreham, C.J.; Horsfield, B.; Schenk, H.J. Predicting the quantities of oil and gas generated fromAustralian Permian coals, Bowen Basin using pyrolyticmethods. Mar. Pet. Geol. 1999, 16, 165-188.

57. Esterle, J.; Smith, G.L.B.; Yago, J. Geometry and connectivity of distributary channel sandstones in the Late Permian Moranbah Coal Measures, Bowen Basin, Australia. APPEA J. 2000, 40, 379-392.

58. Maxwell, K.; Rajabi, M.; Esterle, J. Automated classification of metamorphosed coal from geophysical log data using supervised machine learning techniques. Int. J. Coal Geol. 2019, 214, 103284. [CrossRef]

59. Baker, L.G.; Skerman, W.R. The significance of coal seam gas in eastern Queensland. APPEA J. 2006, 46, 329-342. [CrossRef]

60. Mastalerz, M.; Glikson, M.; Golding, S. Coalbed Methane: Scientific, Environmental and Economic Evaluation; Springer Science \& Business Media: Dordrecht, The Netherlands, 2013.

61. Faiz, M.; Zoitsas, A.; Altmann, C.; Baruch, E.; Close, D. Compositional variations and carbon isotope reversal in coal and shale gas reservoirs of the Bowen and Beetaloo basins, Australia. Geol. Soc. Lond. Spec. Publ. 2020, 484, 51-70. [CrossRef]

62. Esterle, J.; Williams, R. Coal Seam Gas Distribution in the Moranbah-German Creek Coal Measures, Bowen Basin, Queensland. In Petroleum Exploration Society of Australia, Queensland: Exploration and Development; Cowie, M., Ed.; PESA: Brisbane, Australia, 2002.

63. Hoffman, G.L.; Jordan, G.R.; Wallis, G.R. Geophysical Borehole Logging Handbook for Coal Exploration; Coal Mining Research Centre: Edmonton, AB, Canada, 1982.

64. Michaelsen, P.; Henderson, R.A.; Crosdale, P.J.; Mikkelsen, S.O. Facies architecture and depositional dynamics of the Upper Permian Rangal coal measures, Bowen Basin, Australia. J. Sediment. Res. 2000, 70, 879-895. [CrossRef]

65. Yarmohammadtooski, Z.; Salmachi, A.; White, A.; Rajabi, M. Fluid flow characteristics of Bandanna Coal Formation: A case study from the Fairview Field, eastern Australia. Aust. J. Earth Sci. 2017, 64, 319-333. [CrossRef]

66. Ayaz, S.A.; Rodrigues, S.; Golding, S.D.; Esterle, J.S. Compositional variation and palaeoenvironment of the volcanolithic Fort Cooper Coal Measures, Bowen Basin, Australia. Int. J. Coal Geol. 2016, 166, 36-46. [CrossRef]

67. Beeston, J.W. Coal rank variation in the Bowen Basin, Queensland. Int. J. Coal Geol. 1986, 6, 163-179. [CrossRef]

68. Hunt, W.J.; Smyth, M. Origin of inertinite-rich coals of Australian cratonic basins. Int. J. Coal Geol. 1989, 11, 23-46. [CrossRef] 
69. Elliott, L. Post-Carboniferous tectonic evolution of eastern Australia. APPEA J. 1993, 33, 215-236. [CrossRef]

70. Stewart, R.; Adler, D. New South Wales Petroleum Potential; NSW Department of Mineral Resources: Sydney, Australia, 1995.

71. Hammond, R.; Mallet, C. A tectonic framework for coal measure deformation in the southern Bowen Basin. In Advances in the Study of the Sydney Basin, Proceedings of the Twenty First Newcastle Symposium, Newcastle, Australia, 10-12 April 1987; Department of Geology, University of Newcastle: Callaghan, Australia, 1987.

72. Korsch, J.; Boreham, C.; Totterdell, J.; Shaw, R.; Nicoll, M. Development and petroleum resource evaluation of the Bowen, Gunnedah and Surat Basins, eastern Australia. APPEA J. 1998, 38, 199-237. [CrossRef]

73. Tadros, N.Z. The Gunnedah Basin, New South Wales. 1993, Geological Survey of New South Wales. Available online: https: //search.geoscience.nsw.gov.au/product/923 (accessed on 11 May 2020).

74. Sniffin, M.; Beckett, J. Sydney Basin-Hunter Coalfield. In Geology of Australian Coal Basins; Coal Group Special Publication 1; Geological Society of Australia Incorporated: Sydney, Australia, 1995; pp. 177-195.

75. Baker, G.; Slater, S. The Increasing Significance of Coal Seam Gas in Eastern Australia. In Proceedings of the PESA Eastern Australasian Basins Symposium III, Sydney, Australia, 14-17 September 2008.

76. Pinetown, K.L. Regional coal seam gas distribution and burial history of the Hunter Coalfield, Sydney Basin. Aust. J. Earth Sci. 2014, 61, 409-426. [CrossRef]

77. Gurba, W.L.; Weber, C.R. Effects of igneous intrusions on coalbed methane potential, Gunnedah Basin, Australia. Int. J. Coal Geol. 2001, 46, 113-131. [CrossRef]

78. Hamilton, D.S. Deltaic depositional systems, coal distribution and quality, and petroleum potential, Permian Gunnedah basin, N.S.W., Australia. Sediment. Geol. 1985, 45, 35-75. [CrossRef]

79. Hutton, A.C. Geological Setting of Australasian Coal Deposits. The Australasian Institute of Mining and Metallurgy. 2009. Available online: https:/ / ro.uow.edu.au/scipapers/733 (accessed on 2 February 2021).

80. Moffitt, R.S. A Compilation of the Geology of the Southern Coalfield: Notes to Accompany the 1:100 000 Southern Coalfield Geological Map; Geological Survey Report (Geological Survey of New South Wales); no. GS1998/277.; W. Geological Survey of New South, Dept. of Mineral Resources: Sydney, Australia, 2000.

81. Salmachi, A.; Rajabi, M.; Reynolds, P.; Yarmohammadtooski, Z.; Wainman, C. The effect of magmatic intrusions on coalbed methane reservoir characteristics: A case study from the Hoskissons coalbed, Gunnedah Basin, Australia. Int. J. Coal Geol. 2016, 165, 278-289. [CrossRef]

82. Tadros, N.Z. Maceral Composition: Variations and Significance to the Formation of the Hoskissons Coal Member, Gunnedah Basin. 1988, Geological Survey of New South Wales. Available online: https://search.geoscience.nsw.gov.au/product/770 (accessed on 2 February 2021).

83. Faiz, M.; Saghafi, A.; Sherwood, N.; Wang, I. The influence of petrological properties and burial history on coal seam methane reservoir characterisation, Sydney Basin, Australia. Int. J. Coal Geol. 2007, 70, 193-208. [CrossRef]

84. Pratt, W. Gunnedah Coalfield Regional Geology Maps 1:100,000. Explanatory Notes; New South Wales Department of Mineral Resources: Sydney, Australia, 1998.

85. Martin, M.; Wakefield, M.; MacPhail, M.; Pearce, T.; Edwards, H. Sedimentology and stratigraphy of an intra-cratonic basin coal seam gas play: Walloon Subgroup of the Surat Basin, eastern Australia. Pet. Geosci. 2013, 19, 21-38. [CrossRef]

86. Korsch, R.; O’Brien, P.; Sexton, M.; Wake-Dyster, K.; Wells, A. Development of Mesozoic transtensional basins in easternmost Australia. J. Geol. Soc. Aust. 1989, 36, 13-28. [CrossRef]

87. Gallagher, K.; Dumitru, T.A.; Gleadow, A.J.W. Constraints on the vertical motion of eastern Australia during the Mesozoic. Basin Res. 1994, 6, 77-94. [CrossRef]

88. Fielding, C.R. Mesozoic sedimentary basins and resources in eastern Australia. In Geological Society of Australia Abstracts; Geological Society of Australia: Hornsby, Australia, 1996; Volume 43, pp. 180-185.

89. Raza, A.; Hill, K.C.; Korsch, R.J. Mid-Cretaceous uplift and denudation of the Bowen and Surat Basins, eastern Australia: Relationship to Tasman Sea rifting from apatite fission-track and vitrinite-reflectance data. Aust. J. Earth Sci. 2009, 56, 501-531.

90. Smith, T.; Bianchi, V.; Capitanio, F.A. Subduction geometry controls on dynamic topography: Implications for the Jurassic Surat Basin. Aust. J. Earth Sci. 2019, 66, 367-377. [CrossRef]

91. Hamilton, S.K.; Esterle, J.S.; Sliwa, R. Stratigraphic and depositional framework of the Walloon Subgroup, eastern Surat Basin, Queensland. Aust. J. Earth Sci. 2014, 61, 1061-1080. [CrossRef]

92. Hentschel, A.; Esterle, J.; Golding, S.; Pacey, D. Petrologic and stable isotopic study of the Walloon Coal Measures, Surat basin, Queensland: Peat accumulation under changing climate and base level. Int. J. Coal Geol. 2016, 160, 11-27. [CrossRef]

93. Khorasani, G.K. Oil-prone coals of the Walloon Coal Measures, Surat Basin, Australia. Geol. Soc. Lond. Spec. Publ. 1987, 32, 303-310. [CrossRef]

94. Scott, S.; Anderson, B.; Crosdale, P.; Dingwall, J.; Leblang, G. Revised geology and coal seam gas characteristics of the walloon subgroup-Surat basin, Queensland. In Proceedings of the PESA Eastern Australian Basins Symposium II, Adelaide, Australia, 19-22 September 2004; Petroleum Exploration Society of Australia (PESA): Adelaide, Australia, 2004.

95. Goscombe, P.; Coxhead, B. Clarence-Moreton, Surat, Eromanga, Nambour, and Mulgildie Basins. Geol. Aust. Coal Basins 1995, 1, 489-511.

96. Laubach, S.E.; Marrett, R.A.; Olson, J.E.; Scott, A.R. Characteristics and origins of coal cleat: A review. Int. J. Coal Geol. 1998, 35, 175-207. [CrossRef] 
97. Sliwa, R.; Esterle, J. Re-evaluation of structure and sedimentary packages in the eastern Surat Basin. In Proceedings of the Eastern Australasian Basins Symposium III, Sydney, Australia, 14-17 September 2008; PESA: Sydney, Australia, 2008.

98. Wainman, C.C.; McCabe, P.J. Evolution of the depositional environments of the Jurassic Walloon Coal Measures, Surat Basin, Queensland, Australia. Sedimentology 2019, 66, 1673-1699. [CrossRef]

99. Morris, R.J.; Martin, A.M. Coal architecture, high-resolution correlation and connectivity: New insights from the Walloon Subgroup in the Surat Basin of SE Queensland, Australia. Pet. Geosci. 2017, 23, 251-261. [CrossRef]

100. Scott, S.; Anderson, B.; Crosdale, P.; Dingwall, J.; Leblang, G. Coal petrology and coal seam gas contents of the Walloon Subgroup, Surat Basin, Queensland, Australia. Int. J. Coal Geol. 2007, 70, 209-222. [CrossRef]

101. Hamilton, S.K.; Esterle, J.S.; Golding, S.D. Geological interpretation of gas content trends, Walloon Subgroup, eastern Surat Basin, Queensland, Australia. Int. J. Coal Geol. 2012, 101, 21-35.

102. Ovenden, B. Old rocks, new tricks: A reinvigorated Cooper Basin offers growth opportunity. APPEA J. 2019, 59, 928-930. [CrossRef]

103. Gravestock, D.; Hibburt, J.; Drexel, J. Petroleum Geology of South Australia: Cooper Basin; Government of South Australia: Adelaide, Australia, 1998; Volume 4.

104. Strong, P.C.; Wood, G.R.; Lang, S.C.; Jollands, A.; Karalaus, E.; Kassan, J. High resolution palaeogeographic mapping of the fluvial-lacustrine Patchawarra Formation in the Cooper Basin, South Australia. APPEA J. 2002, 42, 65-81. [CrossRef]

105. Mavromatidis, A. Two layer model of lithospheric compression and uplift/exhumation in an intracratonic setting: An example from the Cooper-Eromanga Basins, Australia. Int. J. Earth Sci. 2008, 97, 623-634. [CrossRef]

106. Beeston, J. Coal rank and vitrinite reflectivity. Spec. Publ. the Geol. Soc. Aust. Coal Geol. Group 1995, 1, 83-92.

107. Smyth, M. Organic petrology and clastic depositional environments with special reference to Australian coal basins. Int. J. Coal Geol. 1989, 12, 635-656. [CrossRef]

108. Smith, M.; Cassel, R.; Evans, T. Coal and Coal Seam Gas Resource Assessment for the Cooper Subregion. Product 1.2 for the Cooper Subregion from the Lake Eyre Basin Bioregional Assessment; Department of the Environment, Bureau of Meteorology, CSIRO and Geoscience Australia: Canberra, Australia, 2015; pp. 1-40.

109. Menpes, S.; Hill, A.; Sansome, A. Unconventional Hydrocarbon Plays in the Permian Succession, South Australia. In Proceedings of the Eastern Australian Basins Symposium IV, Brisbane, Australia, 11-14 September 2012; PESA: Brisbane, Australia, 2012; pp. $1-10$.

110. Hughes, W. Gloucester Basin. Geology of Australian Coal Basins; Special Publication; Ward, C.R., Harrington, H.J., Mallett, C.W., Beeston, J.W., Eds.; Geological Society of Australia Incorporated, Coal Geology Group: Sydney, Australia, 1995; Volume 1, pp. 417-430.

111. McVicar, T.; Langhi, L.; Barron, O.; Rachakonda, P.; Zhang, Y.; Dawes, W.; Macfarlane, C.; Holland, K.; Wilkes, P.G.; RaisbeckBrown, N.; et al. Context Statement for the Gloucester Subregion, Product 1.1 from the Northern Sydney Basin Bioregional Assessment; Department of the Environment, Bureau of Meteorology, CSIRO and Geoscience Australia: Canberra, Australia, 2014.

112. Ward, C.R.; Bocking, M.; Ruan, C.-D. Mineralogical analysis of coals as an aid to seam correlation in the Gloucester Basin, New South Wales, Australia. Int. J. Coal Geol. 2001, 47, 31-49. [CrossRef]

113. New South Wales Government. Initial Report-Independent Review of Coal Seam Gas Activities in New South Wales. 2013. Available online: https://www.chiefscientist.nsw.gov.au/_data/assets/pdf_file/0016/31246/130730_1046_CSE-CSG-Julyreport.pdf (accessed on 10 November 2020).

114. Gurba, L.; Weber, C. The relevance of coal petrology to coalbed methane evaluation, using the Gloucester Basin Australia as a model. In Proceedings of the International Coalbed Methane Symposium 2001, Tuscaloosa, AL, USA, 14-16 May 2001; University of Alabama: Tuscaloosa, AL, USA, 2001.

115. Brooke-Barnett, S.; Flottmann, T.; Paul, P.K.; Busetti, S.; Hennings, P.; Reid, R.; Rosenbaum, G. Influence of basement structures on in situ stresses over the Surat Basin, southeast Queensland. J. Geophys. Res. Solid Earth 2015, 120, 4946-4965. [CrossRef]

116. Flottmann, T.; Brooke-Barnett, S.; Trubshaw, R.; Naidu, S.-K.; Kirk-Burnnand, E.; Paul, P.; Busetti, S.; Hennings, P. Influence of in-situ stresses on fracture stimulations in the Surat Basin, southeast Queensland. In SPE Unconventional Resources Conference and Exhibition-Asia Pacific; SPE-167064-MS: Brisbane, Australia, 2013; 14p.

117. Mukherjee, S.; Rajabi, M.; Esterle, J.; Copley, J. Subsurface fractures, in-situ stress and permeability variations in the Walloon Coal Measures, eastern Surat Basin, Queensland, Australia. Int. J. Coal Geol. 2020, 222, 103449. [CrossRef]

118. Rahman, M.K.; Suarez, Y.A.; Chen, Z.; Rahman, S.S. Unsuccessful hydraulic fracturing cases in Australia: Investigation into causes of failures and their remedies. J. Pet. Sci. Eng. 2007, 57, 70-81. [CrossRef]

119. Rajabi, M.; Tingay, M.; King, R.; Heidbach, O. Present-day stress orientation in the Clarence-Moreton Basin of New South Wales, Australia: A new high density dataset reveals local stress rotations. Basin Res. 2017, 29, 622-640. [CrossRef]

120. Tavener, E.; Flottmann, T.; Brooke-Barnett, S. In situ stress distribution and mechanical stratigraphy in the Bowen and Surat basins, Queensland, Australia. Geol. Soc. Lond. Spec. Publ. 2017, 458, 31-47. [CrossRef]

121. Rajabi, M.; Tingay, M.; Heidbach, O. The present-day stress field of New South Wales, Australia. Aust. J. Earth Sci. 2016, 63, 1-21. [CrossRef]

122. Rajabi, M.; Heidbach, O.; Tingay, M.; Reiter, K. Prediction of the present-day stress field in the Australian continental crust using 3D geomechanical-numerical models. Aust. J. Earth Sci. 2017, 64, 435-454. [CrossRef] 
123. Enever, J.; Pattison, C.; McWatters, R.; Clark, I. The relationship between in-situ stress and reservoir permeability as a component in developing an exploration strategy for coalbed methane in Australia. In Proceedings of the EUROCK'94: Rock Mechanics in Petroleum Engineering, Delft, The Netherlands, 29-31 August 1994; CSIRO: Delft, The Netherlands, 1994.

124. Heidbach, O.; Rajabi, M.; Cui, X.; Fuchs, K.; Müller, B.; Reinecker, J.; Reiter, K.; Tingay, M.; Wenzel, F.; Xie, F.; et al. The World Stress Map database release 2016: Crustal stress pattern across scales. Tectonophysics 2018, 744, 484-498. [CrossRef]

125. Gui, F.; Rahman, K.; Lockhart, D.; Cunha, D.; Meadows, D. High Stress Contrast between Different Lithologies and its Implications for Drilling and Stimulation in the Northern Cooper Basin. In Proceedings of the SPE Asia Pacific Oil \& Gas Conference and Exhibition, Perth, Australia, 25-27 October 2016; Society of Petroleum Engineers: Perth, Australia, 2016; p. 16.

126. Hillis, R.; Enever, J.R.; Reynolds, S.D. In situ stress field of eastern Australia. Aust. J. Earth Sci. 1999, 46, 813-825. [CrossRef]

127. Barton, C.A.; Zoback, M.D.; Moos, D. Fluid flow along potentially active faults in crystalline rock. Geology 1995, 23, 683-686. [CrossRef]

128. Ayers, W.B. Coalbed Gas Systems, Resources, and Production and a Review of Contrasting Cases from the San Juan and Powder River Basins. AAPG Bull. 2002, 86, 1853-1890.

129. Olsen, T.N.; Brenize, G.; Frenzel, T. Improvement Processes for Coalbed Natural Gas Completion and Stimulation. In Proceedings of the SPE Annual Technical Conference and Exhibition, Denver, CO, USA, 5-8 October 2003; Society of Petroleum Engineers: Denver, CO, USA, 2003.

130. Hillis, R.R.; Williams, A.F. The Contemporary Stress Field of the Barrow-Dampier Sub-Basin and Its Implications for Horizontal Drilling. Explor. Geophys. 1993, 24, 567-575. [CrossRef]

131. Fisher, K.M.; Warpinski, N.R. Hydraulic-Fracture-Height Growth: Real Data. SPE Prod. Oper. 2012, 27, 8-19. [CrossRef]

132. Zhang, Y.; Underschultz, J.; Langhi, L.; Mallants, D.; Strand, J. Numerical modelling of coal seam depressurization during coal seam gas production and its effect on the geomechanical stability of faults and coal beds. Int. J. Coal Geol. 2018, 195, 1-13. [CrossRef]

133. Diamond, P.W.; Schatzel, S.J. Measuring the gas content of coal: A review. Int. J. Coal Geol. 1998, 35, 311-331. [CrossRef]

134. Pashin, J. Hydrodynamics of coalbed methane reservoirs in the Black Warrior Basin: Key to understanding reservoir performance and environmental issues. Appl. Geochem. 2007, 22, 2257-2272. [CrossRef]

135. Pashin, J.C. Variable gas saturation in coalbed methane reservoirs of the Black Warrior Basin: Implications for exploration and production. Int. J. Coal Geol. 2010, 82, 135-146. [CrossRef]

136. Gurba, W.L.; Ward, C.R. Vitrinite reflectance anomalies in the high-volatile bituminous coals of the Gunnedah Basin, New South Wales, Australia. Int. J. Coal Geol. 1998, 36, 111-140. [CrossRef]

137. Moore, T.A.; Bowe, M.; Nas, C. High heat flow effects on a coalbed methane reservoir, East Kalimantan (Borneo), Indonesia. Int. J. Coal Geol. 2014, 131, 7-31. [CrossRef]

138. Close, J.C. Natural Fractures in Coal: Chapter 5. In Hydrocarbons from Coal; American Association of Petroleum Geologists: Tulsa, OK, USA, 1993.

139. Dawson, W.G.K.; Esterle, J.S. Controls on coal cleat spacing. Int. J. Coal Geol. 2010, 82, 213-218. [CrossRef]

140. Pattison, C.I.; Fielding, C.R.; McWatters, R.H.; Hamilton, L.H. Nature and origin of fractures in Permian coals from the Bowen Basin, Queensland, Australia. Geol. Soc. Lond. Spec. Publ. 1996, 109, 133-150. [CrossRef]

141. Titheridge, D. Drilling induced fractures in coal core from vertical exploration well: A method to determine cleat azimuth, and the angle between cleat and maximum horizontal stress, and its application. In Proceedings of the 14th Coal Operators' Conference, University of Wollongong, The Australasian Institute of Mining and Metallurgy \& Mine Managers Association of Australia, Wollongong, Australia, 12-14 February 2014.

142. Tyson, S.; Hurter, S.; Zhou, F.; Jami, M. Improvements in understanding short-range permeability variability in coal seam gas reservoirs. APPEA J. 2016, 56, 555. [CrossRef]

143. Faraj, B.S.M.; Fielding, C.R.; Mackinnon, I.D.R. Cleat mineralization of Upper Permian Baralaba/Rangal Coal Measures, Bowen Basin, Australia. Geol. Soc. Lond. Spec. Publ. 1996, 109, 151-164. [CrossRef]

144. Keshavarz, A.; Sakurovs, R.; Grigore, M.; Sayyafzadeh, M. Effect of maceral composition and coal rank on gas diffusion in Australian coals. Int. J. Coal Geol. 2017, 173, 65-75. [CrossRef]

145. Chen, D.; Shi, J.-Q.; Durucan, S.; Korre, A. Gas and water relative permeability in different coals: Model match and new insights. Int. J. Coal Geol. 2014, 122, 37-49. [CrossRef]

146. Connell, L. A new interpretation of the response of coal permeability to changes in pore pressure, stress and matrix shrinkage. Int. J. Coal Geol. 2016, 162, 169-182. [CrossRef]

147. Harpalani, S.; Chen, G. Influence of gas production induced volumetric strain on permeability of coal. Geotech. Geol. Eng. 1997, 15, 303-325. [CrossRef]

148. Palmer, I. Permeability changes in coal: Analytical modeling. Int. J. Coal Geol. 2009, 77, 119-126. [CrossRef]

149. Palmer, I.; Mansoori, J. How permeability depends on stress and pore pressure in coalbeds: A new model. SPE Reserv. Eval. Eng. 1998, 1, 539-544.

150. Palmer, I.; Moore, B.; Loftin, D. Cleat Porosity of Coals: New Understanding. In Proceedings of the 3rd Asia-Pacific Coalbed Methane Symposium, Brisbane, Australia, 3-6 May 2011; University of Queensland: Brisbane, Australia, 2011.

151. Gray, I. Reservoir Engineering in Coal Seams: Part 1-The Physical Process of Gas Storage and Movement in Coal Seams. SPE Reserv. Eng. 1987, 2, 28-34. [CrossRef] 
152. Levine, J.R. Model study of the influence of matrix shrinkage on absolute permeability of coal bed reservoirs. Geol. Soc. Lond. Spec. Publ. 1996, 109, 197-212. [CrossRef]

153. Palmer, I. Coalbed methane completions: A world view. Int. J. Coal Geol. 2010, 82, 184-195. [CrossRef]

154. Queensland Government. Queensland Petroleum Exploration Data QPED, M.a.E. Department of Natural Resources, Editor. 2016. Available online: http:/ / qldspatial.information.qld.gov.au/catalogue/custom/search.page?q=\%22Queensland\%20petroleum\% 20exploration\%20data\%20-\%20QPED\%22 (accessed on 6 March 2020).

155. Salmachi, A.; Barkla, J. Investigation of permeability change in the Bandanna Coal Formation of the Fairview Field using time-lapse pressure transient analysis. APPEA J. 2019, 59, 289-301. [CrossRef]

156. Gierhart, R.R.; Clarkson, C.R.; Seidle, J.P. Spatial variation of San Juan Basin Fruitland coalbed methane pressure dependent permeability: Magnitude and functional form. In Proceedings of the International Petroleum Technology Conference, Dubai, United Arab Emirates, 4-6 December 2007.

157. Mazumder, S.; Scott, M.; Jiang, J. Permeability increase in Bowen Basin coal as a result of matrix shrinkage during primary depletion. Int. J. Coal Geol. 2012, 96-97, 109-119.

158. Burgoyne, M.; Shrivastava, R. A practical workflow for characterizing stress-dependent behaviour of coal from changes in well productivity. J. Nat. Gas Sci. Eng. 2016, 33, 1025-1045. [CrossRef]

159. Belushko, I.; Herwin, H.; Gouth, F. Dynamic behavior of a multi-layered coal seams gas reservoir in the Bowen Basin. In Proceedings of the Asia Pacific Oil \& Gas Conference and Exhibition, Adelaide, Australia, 14-16 October 2014; Society of Petroleum Engineers, SPE-171538-MS: Adelaide, Australia, 2014.

160. Clarkson, R.C.; Salmachi, A. Rate-transient analysis of an undersaturated CBM reservoir in Australia: Accounting for effective permeability changes above and below desorption pressure. J. Nat. Gas Sci. Eng. 2017, 40, 51-60. [CrossRef]

161. Clarkson, C.; Jordan, C.; Gierhart, R.; Seidle, J. Production data analysis of CBM wells. In Proceedings of the Rocky Mountain Oil \& Gas Technology Symposium, Denver, CO, USA, 16-18 April 2007; Society of Petroleum Engineers: Denver, CO, USA, 2007.

162. Clarkson, C.R.; Jordan, C.L.; Gierhart, R.R.; Seidle, J.P. Production Data Analysis of Coalbed-Methane Wells. SPE Reserv. Eval. Eng. 2008, 11, 311-325. [CrossRef]

163. Shi, Q.J.; Durucan, S. A Model for Changes in Coalbed Permeability During Primary and Enhanced Methane Recovery. SPE Reserv. Eval. Eng. 2005, 8, 291-299. [CrossRef]

164. Shi, Q.J.; Durucan, S. Exponential growth in San Juan Basin Fruitland coalbed permeability with reservoir drawdown: Model match and new insights. SPE Reserv. Eval. Eng. 2010, 13, 914-925. [CrossRef]

165. Palmer, I.D.; Moschovidis, Z.A.; Cameron, J.R. Coal failure and consequences for coalbed methane wells. In Proceedings of the SPE Annual Technical Conference and Exhibition; Dallas, TX, USA, 9-12 October 2005, Society of Petroleum Engineers: Dallas, TX, USA, 2005.

166. Espinoza, D.N.; Pereira, J.M.; Vandamme, M.; Dangla, P.; Vidal-Gilbert, S. Desorption-induced shear failure of coal bed seams during gas depletion. Int. J. Coal Geol. 2015, 137, 142-151. [CrossRef]

167. Keshavarz, A.; Badalyan, A.; Carageorgos, T.; Bedrikovetsky, P.; Johnson, R. Stimulation of coal seam permeability by micro-sized graded proppant placement using selective fluid properties. Fuel 2015, 144, 228-236. [CrossRef]

168. Wei, C.; Zou, M.; Sun, Y.; Cai, Z.; Qi, Y. Experimental and applied analyses of particle migration in fractures of coalbed methane reservoirs. J. Nat. Gas Sci. Eng. 2015, 23, 399-406. [CrossRef]

169. Bai, T.; Chen, Z.; Aminossadati, S.M.; Rufford, T.E.; Li, L. Experimental investigation on the impact of coal fines generation and migration on coal permeability. J. Pet. Sci. Eng. 2017, 159, 257-266. [CrossRef]

170. Lu, M.; Connell, L. Coal failure during primary and enhanced coalbed methane production-Theory and approximate analyses. Int. J. Coal Geol. 2016, 154, 275-285. [CrossRef]

171. Reisabadi, M.Z.; Haghighi, M.; Sayyafzadeh, M.; Khaksar, A. Effect of matrix shrinkage on wellbore stresses in coal seam gas: An example from Bowen Basin, east Australia. J. Nat. Gas Sci. Eng. 2020, 77, 103280. [CrossRef]

172. Zare Reisabadi, M.; Haghighi, M.; Salmachi, A.; Sayyafzadeh, M.; Khaksar, A. Analytical modelling of coal failure in coal seam gas reservoirs in different stress regimes. Int. J. Rock Mech. Min. Sci. 2020, 128, 104259. [CrossRef]

173. Khanna, A.; Keshavarz, A.; Mobbs, K.; Davis, M.; Bedrikovetsky, P. Stimulation of the natural fracture system by graded proppant injection. J. Pet. Sci. Eng. 2013, 111, 71-77. [CrossRef]

174. Thomson, S.; Thomson, D.; Flood, P. Observations on the distribution of coal seam gas in the Sydney Basin and the development of a predictive model. Aust. J. Earth Sci. 2014, 61, 395-407. [CrossRef]

175. Faiz, M.; Stalker, L.; Sherwood, N.; Saghafi, A.; Wold, M.; Barclay, S.; Choudhury, J.; Barker, W.; Wang, I. Bio-enhancement of coalbed methane resources in the Southern Sydney Basin. APPEA J. 2003, 43, 595-610. [CrossRef]

176. Australian Gas Light (AGL). Hydrogeological Summary of the Camden Gas Project; AGL: Sydney, Australia, $2013 ;$ p. 46.

177. Ryan, D.; Hall, A.; Erriah, L.; Wilson, P. The Walloon coal seam gas play, Surat Basin, Queensland. APPEA J. 2012, 52, 273-290. [CrossRef]

178. Mazumder, S.; Jiang, J.; Sharma, V.; Sugiarto, I. Production Data Analysis of CBM Wells in Surat Basin. In SPE Unconventional Resources Conference and Exhibition-Asia Pacific; Society of Petroleum Engineers: Brisbane, Australia, 2013.

179. Law, B. The relationship between coal rank and cleat spacing: Implications for the prediction of permeability in coal. In Proceedings of the 1993 International Coalbed Methane Symposium, Tuscaloosa, AL, USA, 17-21 May 1993; University of Alabama: Tuscaloosa, AL, USA, 1993. 
180. Esterle, J.; Williams, R.; Sliwa, R.; Malone, M. Variability in Gas Reservoir Parameters that Impact on Emissions Estimations for Australian Black Coals. ACARP project C13071. 2006. Available online: https:/ / www.acarp.com.au/abstracts.aspx?repId=C13071 (accessed on 5 June 2020).

181. Holford, S.; Schofield, N.; Jackson, C.; Magee, C.; Green, P.; Duddy, I. mpacts of igneous intrusions on source and reservoir potential in prospective sedimentary basins along the western Australian continental margin. In Proceedings of the West Australian Basins Symposium, Perth, Australia, 18-21 August 2013.

182. Karacan, C.; Okandan, E. Fracture/cleat analysis of coals from Zonguldak Basin (northwestern Turkey) relative to the potential of coalbed methane production. Int. J. Coal Geol. 2000, 44, 109-125. [CrossRef]

183. Li, H.; Ogawa, Y. Pore structure of sheared coals and related coalbed methane. Environ. Geol. 2001, 40, 1455-1461. [CrossRef]

184. Howell, S.; Furniss, J.; Quammie, K.; Norman, K.; Erriah, L. History matching CSG production in the Surat basin. In Proceedings of the SPE Asia Pacific Oil \& Gas Conference and Exhibition, Adelaide, Australia, 14-16 October 2014; Society of Petroleum Engineers: Adelaide, Australia, 2014.

185. Santos, Dorodillo-2, Well Completion Report (Desorbable Gas Report). 1998: South Australian Department of State Development. Available online: https://sarigbasis.pir.sa.gov.au/WebtopEw/ws/samref/sarig1/wci/ResultSet (accessed on 4 February 2020).

186. Carr, L.K.; Korsch, R.J.; Palu, T.J. Onshore Basin Inventory: The McArthur, South Nicholson, Georgina, Wiso, Amadeus, Warburton, Cooper and Galilee Basins, Central Australia; Record 2016/004; Geoscience Australia: Canberra, Auatralia, 2016.

187. Hall, L.; Hill, A.; Troup, A.; Lawson, C.; Wang, L.; Smith, M. Cooper Basin Architecture and Lithofacies: Regional Hydrocarbon Prospectivity of the Cooper Basin Data Pack 1; Geoscience Australia: Canberra, Australia, 2016. Available online: http:/ /www.ga. gov.au/metadata-gateway/metadata/record/90054 (accessed on 1 February 2020).

188. Geoscience Australia. Australian Geological Provinces v02, Geoscience Australia, Canberra, Australia. 2013. Available online: https:/ / data.gov.au/data/dataset/9ff62603-2aba-44d0-bb4b-165ee66c4cac (accessed on 10 March 2020).

189. Strike Energy, Well Completion Report for Le Chiffre 1. 2014. Available online: https://sarigbasis.pir.sa.gov.au/WebtopEw/ws / samref/sarig1/wci/ResultSet (accessed on 2 February 2021).

190. Strike Energy, Jaws-1 Technical Update. 2018. Available online: https://strikeenergy.com.au/asx-announcements / (accessed on 5 February 2021). 